\title{
Community dynamics on a subtidal cobble bed following mass mortalities of sea urchins
}

\author{
Robert E. Scheibling, Bruce G. Raymond* \\ Department of Biology, Dalhousie University, Halifax, Nova Scotia, Canada B3H 4J1
}

\begin{abstract}
The macrobenthic community of a shallow subtidal cobble bed at Eagle Head on the Atlantic coast of Nova Scotia was monitored from ca 4 mo before to 41 mo after mass mortalities of sea urchins Strongylocentrotus droebachiensis in September 1983. Biomass of erect algae on cobbles increased from 0 to between 50 and $75 \mathrm{~g}$ (dry weight) $\mathrm{m}^{-2}$ after the sea urchin die-off, and consisted mainly of small and sparsely distributed plants of Fucus evanescens and Chondrus crispus. In contrast, algal biomass increased from 0 to $\mathrm{ca} 2.8 \mathrm{~kg} \mathrm{~m}^{-2}$ on an adjacent boulder ridge where large kelps (Laminaria longicruris, L. digitata, Saccorhiza dermatodea) formed a dense canopy. The macroflora of cobble beds at 2 other sites was similar in biomass and composition to the cobble bed at Eagle Head. At a third site, the sea urchin population had recovered and precluded the establishment of non-calcareous algae on the cobbles. In the absence of sea urchins, herbivorous molluscs, mainly perwinkles Littorina littorea, limpets Notoacmaea testudinalis and chitons Tonicella rubra, dominated the cobble macrofauna, reaching densities of up to ca 150,400, and 1300 ind. $\mathrm{m}^{-2}$ respectively at Eagle head. However, these grazers (and other organisms) suffered mass mortalities in summer 1986, when thick mats of drift algae inundated the bottom creating anoxic conditions. Suspension feeders consisted mainly of small bivalves of which juvenile mussels (Modiolis modiolis, Mytilis edulis) were most abundant. Predators/ scavengers included crabs, lobsters, whelks, sea stars, and polychaetes, many of which were small and seasonally active. With the exception of juvenile mussels, which increased in abundance (but rarely reached adult size), there was no evidence of a numerical response among macrofaunal populations to the elimination of sea urchins.
\end{abstract}

\section{INTRODUCTION}

Disease is a selective agent of mortality, usually affecting only one or a few species in a given community. However, if a susceptible species plays a key functional role in the community, its removal by disease may have dramatic repercussions for the community as a whole. The importance of disease in regulating marine populations and communities has become widely recognized (Kinne 1980), particularly with the discovery of major epizootics in sea urchins (e.g. Pearse \& Hines 1979, Bourdouresque et al. 1981, Lessios et al. 1984a, b, Carpenter 1985, 1988, Liddle \& Ohlhorst 1986, Scheibling 1986, Hughes et al. 1987. Levitan 1988).

In the early 1980 's, mass mortalities of the sea urchin, Strongylocentrotus droebachiensis, due to an amoebic disease (Jones \& Scheibling 1985, Scheibling 1988),

- Present address: P. Lane \& Associates, 49 Pownal St., Charlottetown, Prince Edward Island, Canada CA1 7N9 significantly altered the structure of rocky subtidal communities off the Atlantic coast of Nova Scotia, Canada. Release from grazing pressure enabled seaweeds to rapidly colonize areas formerly denuded by sea urchins ('barren grounds') and culminated in the emergence of luxuriant kelp beds along hundreds of kilometers of coast (Scheibling 1984b, 1986, Miller 1985a, Johnson \& Mann 1988). The prolific growth of kelps and other seaweeds has occurred on boulder fields and bedrock outcrops which comprise most of the rocky subtidal zone off Nova Scotia (Moore \& Miller 1983). Cobble beds, which occur along some $12 \%$ of rocky coastline (our analysis of data given in Moore \& Miller 1983), represent habitat patches with distinctive physical characteristics, but little is known about their biotic communities and how they respond to this type of disturbance.

Strongylocentrotus droebachiensis was abundant ( $>100$ ind $\mathrm{m}^{-2}$ ) in a cobble bed at Eagle Head in southwestern Nova Scotia before it was eliminated by recurrent outbreaks of disease in 1982-1983 (Scheib- 
ling 1984a, Scheibling \& Stephenson 1984). During the period of sea urchin dominance, the cobbles were encrusted with coralline algae and erect algae were virtually absent (as was the case on boulder and bedrock habitats in surrounding areas). The catastrophic mortality, therefore, afforded a rare opportunity to examine the role of sea urchins in this cobble bed community and the direct and indirect effects of their removal on the component populations.

Although we expected biomass of erect algae to increase following the sea urchin die-off, we predicted that, due to the small size and potential instability of cobbles, kelps and other large macroalgae would not predominate, as they do on more stable rocky substrata. This prediction was supported by previous studies showing that macroalgal assemblages in cobble beds (where sea urchins and other large grazers were rare) differ markedly in composition and biomass from those on neighbouring rocky outcrops and ridges (Lieberman et al. 1979, 1984, Davis \& Wilce 1987). Such differences have been attributed to periodic physical disturbance of cobbles by waves and currents which abrades and destroys larger plants and favours the establishment of small, turf-forming species. Crustose algae, which are well adapted to withstand disturbance (see review by Steneck 1986), also predominate in such environments (Davis \& Wilce 1987). However, reduced grazing pressure may alter competitive (overgrowth) interactions among coralline crusts (Paine 1984, Steneck 1986), and we might expect a change in the relative abundance of encrusting species, if indeed sea urchins were important grazers of corallines in this cobble bed.

Among the most common herbivores which co-occur with sea urchins off Nova Scotia (and elsewhere along the northwest Atlantic coast) are periwinkles Littorina littorea, limpets Notoacmea testudinalis and chitons Tonicella spp. (Steneck 1982, Logan et al. 1984, Michaud 1986, Ojeda \& Dearborn 1989). If these species compete with Strongylocentrotus droebachiensis, we might expect them to exhibit a numerical or functional response to the elimination of sea urchins. Significant increases in the abundance of limpets (Acmaea $=$ Notoacmaea testudinalis) and other small herbivores have been observed 1 to 2 yr after experimental removal of $S$. droebachiensis in the St Lawrence Estuary (Himmelman et al. 1983) and in Norway (Sandnes \& Gulliksen 1980). Similarly, increases in the abundance of other sea urchins (Lessios et al. 1984b) and in the feeding rate of herbivorous fish (Carpenter 1988) have been attributed to competitive release following mass mortalities of Diadema antillarum in the Caribbean.

Finally, we might expect indirect effects of the sea urchin die-off on benthic populations in general via increases in macroalgal abundance both within and outside the cobble bed. Increases in abundance of predators (e.g. Iobsters) may be mediated by increased productivity and habitat complexity (Wharton \& Mann 1981, Johns \& Mann 1987, but see also Miller 1985b, Elner \& Campbell 1987). Perhaps a more immediate effect would be an increase in drift algae arising from the burgeoning kelp beds on boulder and bedrock substrata. The accumulation of dense mats of drift algae, particularly in depositional environments such as the cobble bed at Eagle Head (Scheibling \& Stephenson 1984), may restrict recruitment of benthic plants and animals to the bottom (Olafsson 1988) or alter species abundance through changes in the physical environment (Thrush 1986).

To assess these predictions, we monitored the abundance of individual populations (both macroflora and macrofauna, but excluding infauna of underlying sediments and endolithic species within coralline crusts) on the cobble bed at Eagle Head from about 4 mo prior to the elimination of sea urchins to almost 3.5 yr thereafter. We contrast the developing macroalgal-grazer assemblage at this site to those of other cobble beds along this coast (where sea urchins were concurrently eliminated), and to a kelp bed community on an adjacent boulder ridge. The observed patterns give insight into the relative roles of biological and physical disturbances in regulating population and community structure on cobble substrata, and provide a basis for formulating testable hypotheses about their effects.

\section{MATERIALS AND METHODS}

The major study site was a cobble bed at Eagle Head on the southwestern coast of Nova Scotia (Fig. 1). The bed lies at a depth of 2 to $3 \mathrm{~m}$ (below mean low water) in a small nearshore basin (ca $5000 \mathrm{~m}^{2}$ ) bounded by a submerged (ca $0.5 \mathrm{~m}$ depth) ridge of boulders along i.ts offshore extent and by a man-made breakwater along one side. The site is exposed to the open ocean over an angle of $90^{\circ}$ (SSW to ESE), although the boulder ridge dissipates much of the incoming wave energy. Strong onshore winds (>40 $\mathrm{km} \mathrm{h}^{-1}$ ) were most frequent, and mean onshore windspeed was highest, in winter (Western Head Station, Atmospheric Environment Service, Environment Canada, unpubl.). Bottom seawater temperature showed pronounced seasonal fluctuations ranging from 1 to $2^{\circ} \mathrm{C}$ in February/March to 16 to $18^{\circ} \mathrm{C}$ in August/September. Salinity of the bottom water ranged from 30 to $32 \%$.

The cobbles are composed of graywacke (a sedimentary rock) and largely encrusted with coralline algae of 3 genera. Lithothamnium, Clathromorphum, Phymatolithon. Throughout most of the bed, a closely- 


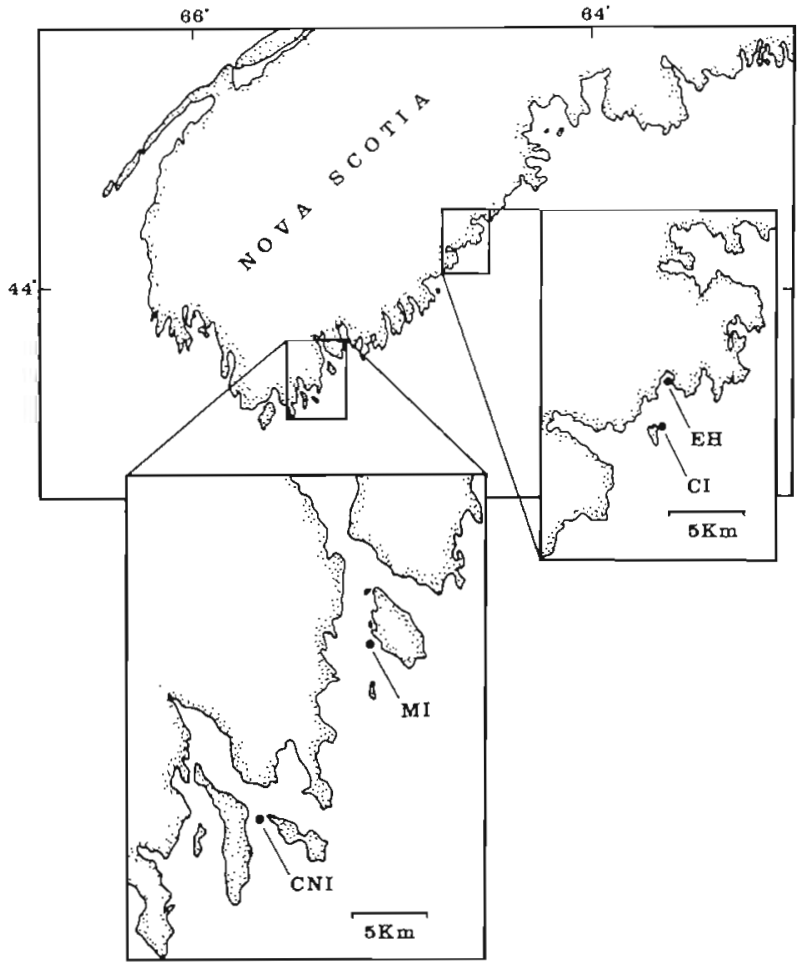

Fig. 1. Southwestern Nova Scotia, Canada, showing location of study sites at Eagle Head (EH), Coffin Island (CI), MCNutt Island (MI), and Cape Negro Island (CNI)

packed layer of cobble overlies a sub-layer partially buried in fine sand. Excavations within the bed revealed an accretion of cobble and sediment to at least 30 to $40 \mathrm{~cm}$ depth. The cobble grades to sand and mud in the deepest part of the basin (ca $3.5 \mathrm{~m}$ depth) and to progressively larger rocks along the shoreward slope of the boulder ridge.

We sampled the macrobenthic community on cobbles at Eagle Head at 2 to 3 mo intervals from June 1983 (before sea urchins were completely eliminated in September 1983) to February 1987. Samples were collected using SCUBA from within a $5 \times 50 \mathrm{~m}\left(250 \mathrm{~m}^{2}\right)$ grid centrally located in the cobble bed. The grid was delineated by a fixed $50 \mathrm{~m}$ transect line and a moveable $5 \mathrm{~m}$ line extended perpendicular to it; both lines were graduated at $1 \mathrm{~m}$ intervals. Large, vagile predators (crabs, lobsters and fish) were censused within the entire grid (except when dense mats of drift algae occluded a view of the bottom). Macro-invertebrates larger than $1 \mathrm{~cm}$ (e.g. periwinkles, whelks, crabs, sea stars, polychaetes) were sampled in fifteen, $50 \times 50 \mathrm{~cm}$ $\left(0.25 \mathrm{~m}^{2}\right)$ quadrats randomly located within the grid at each sampling date. Smaller, more sedentary invertebrates (e.g. chitons, limpets, juvenile sea urchins and mussels) and attached algae were sampled by collecting cobble within a $25 \times 25 \mathrm{~cm}\left(0.0625 \mathrm{~m}^{2}\right)$ quadrat inset within the larger quadrat lexcept for the first 2 sampling dates when they were collected within five $0.25 \mathrm{~m}^{2}$ quadrats). Quadrat samples were placed in separate plastic bags and sealed underwater The samples were transported in coolers to the laboratory where they were stored frozen for less than $1 \mathrm{wk}$ before processing.

In the laboratory, cobble samples were thawed in seawater and carefully scrutinized for small plants and invertebrates. Macroalgae were removed from cobbles and the primary (bare rock) or secondary (crustose coralline algae) substratum beneath the holdfast was recorded. The number of plants and the maximum frond length of non-filamentous species (e.g. Fucus, Chondrus, kelps) were measured (1 mm accuracy) from November 1985 onward. Plants were sorted by species and oven dried to a constant weight at $80^{\circ} \mathrm{C}$. Macrofauna also were sorted by species (except for amphipods and juvenile mussels), counted and measured (1 $\mathrm{mm}$ accuracy). Shell length was recorded for chitons, snails and bivalves, carapace width for crabs (except hermit crabs where carapace length was measured), arm radius for sea stars, horizontal test diameter for sea urchins, and disc diameter for brittle stars. Dry weights of invertebrate species were estimated from size measurements using linear regression equations ( $\log$ transformed data, $\mathrm{r}^{2}>0.89$ ), except for amphipods, brittle stars and the bivalve Anomia sp. for which pooled samples of 20 (brittle stars, Anomia) or 100 (amphipods) individuals were weighed to estimate the average dry weight per individual.

The cobbles were air-dried and weighed, and length, width and height were measured ( $1 \mathrm{~mm}$ accuracy). The surface area of cobbles was estimated from measurements of length, width, height and dry weight using a multiple regression equation: $\mathrm{A}=53.5+0.49 \mathrm{X}_{1}+$ $0.675 X_{2}+3.24 X_{4}$, where $A$ is surface area in $\mathrm{cm}^{2} ; X_{1}$, $X_{2}$, and $X_{3}$ are length, width and height respectively in $\mathrm{mm}$, and $\mathrm{X}_{4}$ is the square root of dry weight in $\mathrm{g}\left(\mathrm{r}^{2}=\right.$ $0.82, p \ll 0.001)$. The regression equation was based on measurements of a random sample of cobbles $(\mathrm{N}=83)$ taken in June 1985. Surface area was measured indirectly by a surface film technique. Each cobble was dipped twice in liquid paraffin at $61 \pm 1{ }^{\circ} \mathrm{C}$ to coat it with a wax film $2 \mathrm{~mm}$ thick. The wax-coated cobble was weighed (1 $\mathrm{mg}$ accuracy), dipped again, and reweighed. The difference in weights was the weight of the top layer of wax $1 \mathrm{~mm}$ thick. A cork borer was used to excise 2 discs of $1 \mathrm{~cm}$ diam. from the top layer. The discs were weighed and the mean weight was used to determine the proportionality between the weight of the top layer of wax and the surface area $\left(0.78 \mathrm{~cm}^{2}\right.$ for each disc) which in turn was used to estimate the surface area of each cobble from the total weight of the top layer of wax. 
The percentage cover of bare rock (i.e. nonencrusted but with a microbial film), and of each taxon of crustose coralline alga, was visually estimated (to the nearest $10 \%$ ) for each cobble. This was multiplied by the surface area of the cobble (determined by the regression equation given above) to estimate the area of each type of cover. The total areal cover of bare rock and each coralline taxon per unit area of bottom $\left(1 \mathrm{~m}^{2}\right)$ was then calculated by summing the respective areal cover over all cobbles in a sample.

Cobble beds at 3 other sites along the southwestern shore (Fig. 1), Coffin Island, McNutt Island, Cape Negro Island, were sampled in May 1987 for comparison with Eagle Head. The sites were located at a depth of 3 to $4 \mathrm{~m}$ off islands with extensive cobble beaches. All were in areas where mass mortalities of sea urchins occurred in the fall of 1983 (Scheibling 1986). At each site, macroalgae and grazers were sampled in 15 randomly-placed $0.25 \mathrm{~m}^{2}$ quadrats with $0.0625 \mathrm{~m}^{2}$ insets as described above.

To compare the macroalgal-grazer assemblage which developed on boulders to that on cobbles, 15 randomly-placed $0.25 \mathrm{~m}^{2}$ quadrats were sampled on the boulder ridge adjacent to the cobble bed at Eagle Head in June 1987. Large kelp plants and sea urchins were sampled in the entire $0.25 \mathrm{~m}^{2}$ quadrat; small macroalgae and grazers were sampled in the $0.0625 \mathrm{~m}^{2}$ insets. Macroalgae were removed from boulders at the holdfast using metal scrapers; cobbles with attached algae and grazers were collected in plastic bags. Boulders within each quadrat were overturned and carefully searched for sea urchins.

\section{RESULTS}

\section{Crustose algae}

The cobble bed at Eagle Head is a relatively homogeneous substratum: $>90 \%$ of cobbles $(\mathrm{N}=1555$, pooled for quadrat samples from March 1984 to February 1987 ) are 4 to $10 \mathrm{~cm}$ in length (mean $\pm \mathrm{SD}: 6.9$ $\pm 1.9 \mathrm{~cm}), 40$ to $400 \mathrm{~g}$ in dry weight $(164.0 \pm 160.2 \mathrm{~g})$, and 10 to $100 \mathrm{~cm}^{2}$ in surface area $\left(44.1 \pm 25.7 \mathrm{~cm}^{2}\right)$. The size distribution of cobbles did not change during the study (mean length $\pm \mathrm{SD}$ was ca $7 \pm 2 \mathrm{~cm}$ at all sampling dates).

The cobbles were heavily encrusted by coralline algae which covered 70 to $80 \%$ of the cobble surface (Fig. 2). The smooth crust Clathromorphum circumscriptum was the most abundant species, occurring on $79 \%$ of cobbles ( $N=1170$ ) and generally covering 40 to $45 \%$ of the cobble surface. Next most abundant was Lithothamnium, a branched crust, occurring on $71 \%$ of cobbles and covering 20 to $30 \%$ of the cobble surface.

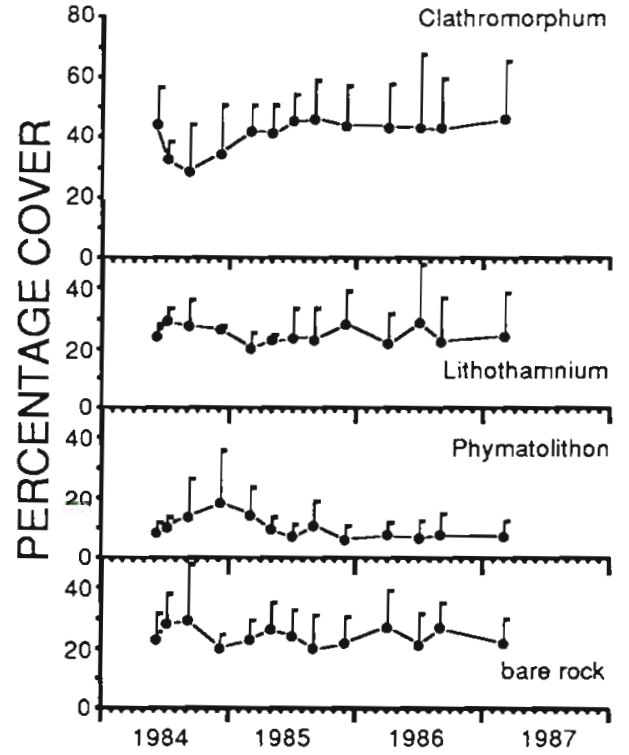

Fig. 2. Mean percentage cover of cobbles, per $\mathrm{m}^{2}$ of bottom, by coralline algae (Clathromorphum, Lithothamnium, PhymatoLithon) and bare rock between 1984 and 1987 at Eagle Head Error bars are one standard deviation. From March 1984 to June 1985, cover was measured in 3 randomly-selected quadrats; From August 1985 to February 1987, cover was measured in all 15 quadrats sampled

Two species were present, L. glaciale and L. lemoineae, although the latter was found on only $3 \%$ of cobbles and both species were pooled for analyses. Thick crusts of Lithothamnium often accreted around a small pebble nucleus forming spheroidal nodules or rhodoliths. These crusts were extensively pitted and undercut providing numerous microhabitats for cryptofauna. Phymatolithon, another smooth crust, also was represented by 2 morphologically similar species, $P$. laevigatum and $P$. rugulosum, that were pooled for analyses. Phymatholithon occurred on $36 \%$ of cobbles and covered 5 to $15 \%$ of the cobble surface. Cobbles generally were encrusted with more than one coralline taxon, although Phymatolithon and Lithothamium did occur as monocultures (the latter in the form of nodules) on some cobbles. C. circumscriptum, the dominant species, invariably co-occurred with other corallines, often overgrowing Phymatolithon where the 2 species overlapped. Bare (non-encrusted) rock usually occurred on the undersides of cobbles, particularly the larger ones $(>10 \mathrm{~cm})$; smaller cobbles were often coated entirely with live coralline algae. The mean cover of each coralline type (Fig. 2) did not vary significantly between 1984 and 1987 (ANOVA, arcsine transformed data, $p>0.20$ ). Nearly all corallines on cobbles collected prior to August 1986 were a healthy pink colour (a few dead patches occurred on the undersides of some larger cobbles\}. However, in the last 2 samples, 
corallines on many of the cobbles which had been inundated by a dense mat of drift algae (see below) were blanched and presumably dead.

Fleshy red and brown algal crusts, including Hildenbrandia rubra, Ralfsia clavata, Petroderma maculiforme and Pseudolithoderma sp., were occasionally observed on cobbles. They usually occurred in small colonies (only a few millimetres in diameter) on bare rock surfaces or on Phymatolithon.

\section{Erect macroalgae}

Following the mass mortality of sea urchins in September 1983, small algal germlings (mainly Fucus evanescens and Chondrus crispus) began appearing on the cobble in early 1984 (Fig. 3, Appendix 1). Erect macroalgal biomass (dry weight) increased gradually thereafter to $75 \mathrm{~g} \mathrm{~m}^{-2}$ by June 1986. F. evanescens and C. crispus were the predominant fleshy algal species on the cobble bottom throughout this study (Fig. 3). Mean densities of $F$. evanescens and $C$. crispus ranged from 42 to 112 plants $\mathrm{m}^{-2}$ and 26 to 52 plants $\mathrm{m}^{-2}$ respectively, between November 1985 and February 1987 (Table 1), but did not differ significantly among sampling dates during this period (ANOVA, log-transformed data, $p>0.10$ ). Populations of both species consisted mostly of small, sparsely-distributed juvenile plants: mean frond lengths ( $\pm \mathrm{SD}$ ) were 41.4 ( \pm 44.8) $\mathrm{mm}$ for $F$. evanescens and 29.4 ( \pm 25.8 ) $\mathrm{mm}$ for C. crispus ( $\mathrm{N}=$ 309 and 182 respectively, pooled from quadrat samples collected between November 1985 and February 1987). Frequencies of occurrence of $F$. evanescens and $C$. cripsus on bare (non-encrusted) rock and coralline algae were disproportionate to the relative cover of each substratum type (Table 2). F. evanescens occurred almost exclusively on Lithothamnium. C. crispus was most abundant on bare rock where its occurrence significantly exceeded that expected from a random distribution $\left(\chi^{2}=151.8, p \ll 0.001\right)$; its frequency of occurrence on different corallines was similar, and significantly lower than expected on Clathomorphum $\left(\chi^{2}=245.6, \mathrm{p} \ll 0.001\right)$.

Juvenile kelp plants, including Laminaria digitata, $L$. longicruris, Alaria esculenta and Saccorhiza dermatodea, occurred sporadically on the cobble bottom at densities of up to 4 plants $\mathrm{m}^{-2}\left(13 \mathrm{~g} \mathrm{~m}^{-2}\right)$ (Table 1). These kelps were generally $<30 \mathrm{~cm}$ in length; the largest recorded plant was $91 \mathrm{~cm}$. Desmarestia viridis, an annual brown alga, was present in low abundance in the summers of $1984\left(3 \mathrm{~g} \mathrm{~m}^{-2}\right)$ and $1985\left(6 \mathrm{~g} \mathrm{~m}^{-2}\right)$ but was rare in 1986 (Fig. 3). A filamentous red alga, Polysiphonia harveyi, was present $\left(1\right.$ to $5 \mathrm{~g} \mathrm{~m}^{-2}$ ) in 1985 only (Fig. 3). Several other small, filamentous and branching species, including an erect coralline alga,

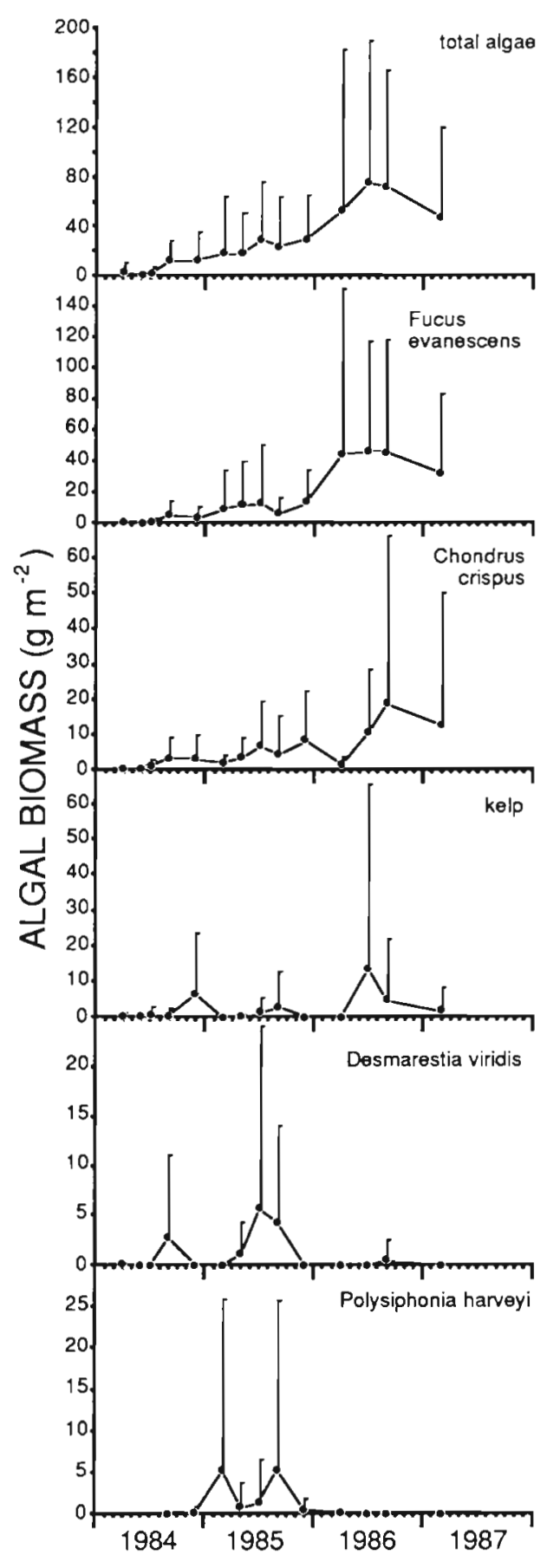

Fig. 3. Mean biomass of total algae and major species (Fucus evanescens; Chondrus crispus; Desmarestia viridis; kelps, including Laminaria longicruris, L. digitata, Saccorhiza dermatodea, Alaria esculenta; Polysiphonia harveyi between 1984 and 1987 on the cobble bed at Eagle Head. Error bars are one standard deviation

Corallina officinalis, were consistently rare $\left(<3 \mathrm{~g} \mathrm{~m}^{-2}\right)$ throughout the study (Appendix 1).

The number of species of erect macroalgae in the cobble bed fluctuated seasonally, usually increasing in 
Table 1 Mean and standard deviation (in parentheses) density (ind. $\mathrm{m}^{-2}$ ) of major species of erect macroalgae on cobble bed at Eagle Head between November 1985 and February 1987. Data are for 15 random $0.0625 \mathrm{~m}^{2}$ quadrats

\begin{tabular}{|c|c|c|c|c|c|}
\hline Algal species & 23 Nov 1985 & 4 Mar 1986 & 20 Jun & 22 Aug & 27 Feb 1987 \\
\hline Fucus evanescens & $68(61)$ & $51(68)$ & $112(128)$ & $58(64)$ & $42(54)$ \\
\hline Chondrus crispus & $34(30)$ & $44 \quad(45)$ & $52 \quad(47)$ & $26(29)$ & 42 (53) \\
\hline Kelp species ${ }^{d}$ & $2 \quad(6)$ & 0 & $4 \quad(12)$ & 2 (6) & $4(12)$ \\
\hline
\end{tabular}

Table 2. Percentage cover of coralline algal genera and bare rock, and observed and expected (below, in parentheses) distribution of Fucus evanescens and Chondrus crispus on each substratum type. Data are for 75 random $0.0625 \mathrm{~m}^{2}$ quadrat samples pooled from November 1985 to August 1986; pooled sample sizes for F. evanescens and C. crispus were 309 and 182 plants respectively. Chi-square Goodness-of-Fit tests compare the observed distributions of $F$. evanescens and $C$. crispus with those expected by a random distribution (i.e. proportional to the relative cover of each substratum type)

\begin{tabular}{|c|c|c|c|c|c|c|}
\hline & Lithothamnium & Phymatolithon & Clathromorphum & Bare rock & $x^{2}$ & $\mathrm{p}$ \\
\hline$\%$ Cover & 25.8 & 7.9 & 41.6 & 24.6 & & \\
\hline $\begin{array}{l}\text { Distribution of } \\
\text { Fucus evanescens }\end{array}$ & $\begin{array}{l}294 \\
(80)\end{array}$ & $\begin{array}{c}1 \\
(24)\end{array}$ & $\begin{array}{c}4 \\
(129)\end{array}$ & $\begin{array}{c}10 \\
(76)\end{array}$ & 772.8 & $<0.001$ \\
\hline $\begin{array}{l}\text { Distribution of } \\
\text { Chondrus crispus }\end{array}$ & $\begin{array}{c}31 \\
(47)\end{array}$ & $\begin{array}{c}26 \\
(14)\end{array}$ & $\begin{array}{c}26 \\
(76)\end{array}$ & $\begin{array}{c}99 \\
(45)\end{array}$ & 113.5 & $\ll 0.001$ \\
\hline
\end{tabular}

summer or fall due to the emergence of annual species (e.g. Desmarestia viridis, Polysiphonia harveyi, Saccorhiza dermatodea) (Appendix 1). The maximum number of species recorded in a sample was 15 (August 1986); usually only 6 to 8 species were found on the cobble bed over winter. A total of 25 species of erect macroalgae (12 Rhodophyta, 11 Phaeophyta, 2 Chlorophyta) were recorded on cobbles throughout the study (Appendix 1).

\section{Drift algae}

After the sea urchin die-off, extensive mats of drift algae accumulated on the cobble bed in the summer and fall of each year but were generally absent during winter In 1984-1985 these mats covered almost half of the sampling grid in June/July. During the next $2 \mathrm{yr}$, their cover increased, approaching $100 \%$ in May and June. The mats consisted of a variety of algal species including kelps (Laminaria longicruris, L. digitata, Alaria escalentus, Saccorhiza dermotodea, Agarum cribosum). Desmarestia aculeata and $D$. viridus, intertidal rockweeds (Fucus vesiculosus, Ascophyllum nodosum) and filamentous red algae (Ptilota serrata, Ceramium rubrum). The composition of these mats varied, although kelps, particularly Laminaria, were generally predominant (except in spring 1987 when rockweeds and filamentous red algae were most abundant).

The detrital material, derived from luxuriant subtidal and intertidal algal assemblages in neighbouring areas, was deposited by currents in the basin. Strong gales (which are more prevalent in winter) flush the basin and may account for the seasonal disappearance of the mats each year. The mats often extended over much of the grid area, leaving only the slightly shallower southern end and parts of the western border uncovered. The dense accumulation of drift algae, usually between 20 and $50 \mathrm{~cm}$ deep, resulted in aphotic, stagnant conditions on the cobble bottom. This undoubtedly had a detrimental impact on plant growth, and may account for the paucity of fleshy algae observed in the deeper parts of the study grid. In summer 1986 , anoxic conditions (surface sediments were black and smelled of hydrogen sulfide), resulting from the prolonged residence of a particularly dense algal mat, caused extensive mortalities of coralline algae (see above) and small grazers (see below).

\section{Herbivores and detritivores}

Strongylocentrotus droebachiensis was the dominant herbivore (in terms of biomass) on the cobble bed prior to its elimination by disease. An initial outbreak of disease in October 1982 reduced the population by ca $70 \%$ (Scheibling \& Stephenson 1984). Surviving sea urchins continued to preclude the establishment of erect macroalgae and readily consumed drift algae deposited in the cobble bed from surrounding intertidal areas. A 

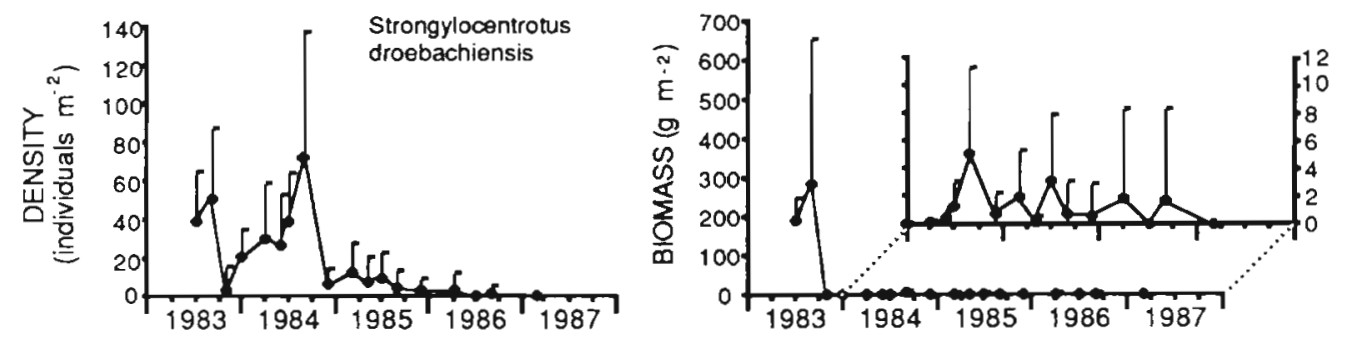

Fig. 4. Strongylocentrotus droebachiensis. Mean density and biomass of sea urchins between 1983 and 1987 at Eagle Head. Error bars are one standard deviation

recurrence of disease in September 1983 completely eliminated sea urchins at Eagle Head (Fig. 4) and elsewhere along the coast (Scheibling 1986). Recruitment of $S$. droebachiensis occurred shortly after the dieoff (Fig. 5a). The modal size class increased to 6 to $7 \mathrm{~mm}$ by late August 1984 (Fig. 5a), consistent with growth rates measured in previous studies (Scheibling 1986, Raymond \& Scheibling 1987). Another cohort had recruited by August 1984 (Fig. 5a), increasing the density of juvenile sea urchins to 72 ind. $\mathrm{m}^{-2}$ (Fig. 4), but their numbers then dropped sharply to 6 ind. $\mathrm{m}^{-2}$ by mid November 1984. There was no further recruitment in 1985; the population continued to dwindle and effectively disappeared from the cobble bed by late 1986 .

Following the mass mortality of sea urchins, the periwinkle Littorina littorea became the most important herbivore in terms of biomass (Fig. 6). Mean biomass of periwinkles ranged from 101 to $458 \mathrm{~g} \mathrm{~m}^{-2}$, and mean density from 35 to 146 ind. $\mathrm{m}^{-2}$, between June 1983 and February 1987. There was significant variation among months in both measures of abundance (ANOVA, log-transformed data, $\mathrm{p}<0.001$ ) but no clear trend. A significant decrease in abundance (SNK test, $p<0.05$ ) between June and August 1986 coincided with the accumulation of a dense mat of drift algae which overlaid the cobble bottom during most of this period. On 22 August 1986, shortly after the mat was flushed from the basin, empty shells of dead periwinkles, chitons and limpets were found on the bottom. Many of these animals probably died of anoxia resulting from prolonged cover by the thick mat during peak seawater temperatures.

Littorina littorea generally foraged over surface of the cobble bed, but occasionally formed aggregations on drift kelp. When temperatures were low in winter and spring, many periwinkles were inactive beneath the surface layer of cobble, often partially buried in the sediment. Mean shell length of periwinkles was about $22 \mathrm{~mm}$ throughout the study (Fig. 7). A few, small periwinkles $(<12 \mathrm{~mm})$ were present in most samples indicating a continous trickle of recruits, and the population became skewed towards smaller sizes in 1985-1986

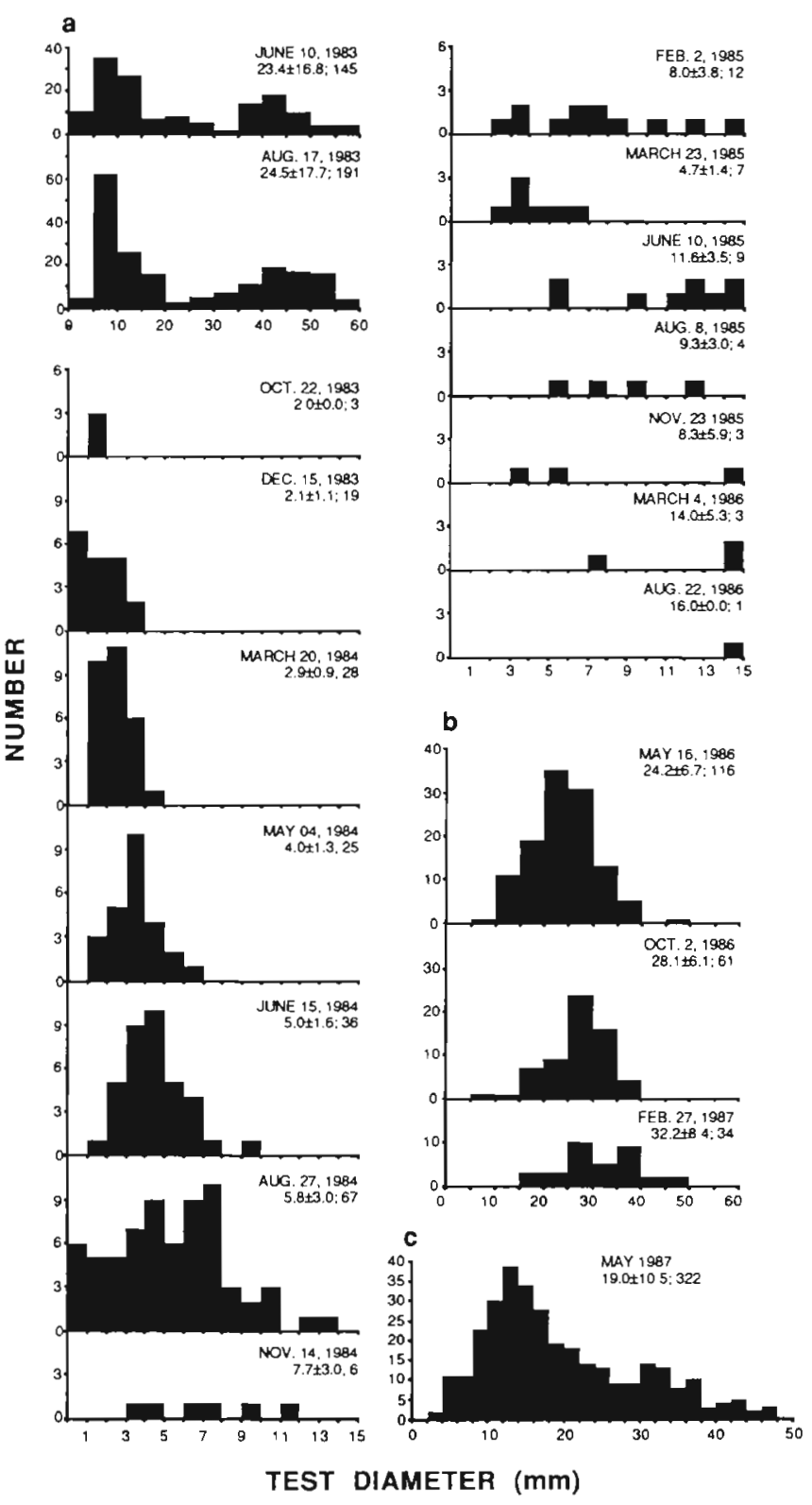

Fig. 5. Strongylocentrotus droebachiensis. Size-frequency distributions of sea urchins on: (a) cobble bed and, (b) boulder ridge at Eagle Head between 1983 and 1987; (c) cobble bed at Cape Negro Island in May 1987. Data are mean \pm SD test diameter and sample size 

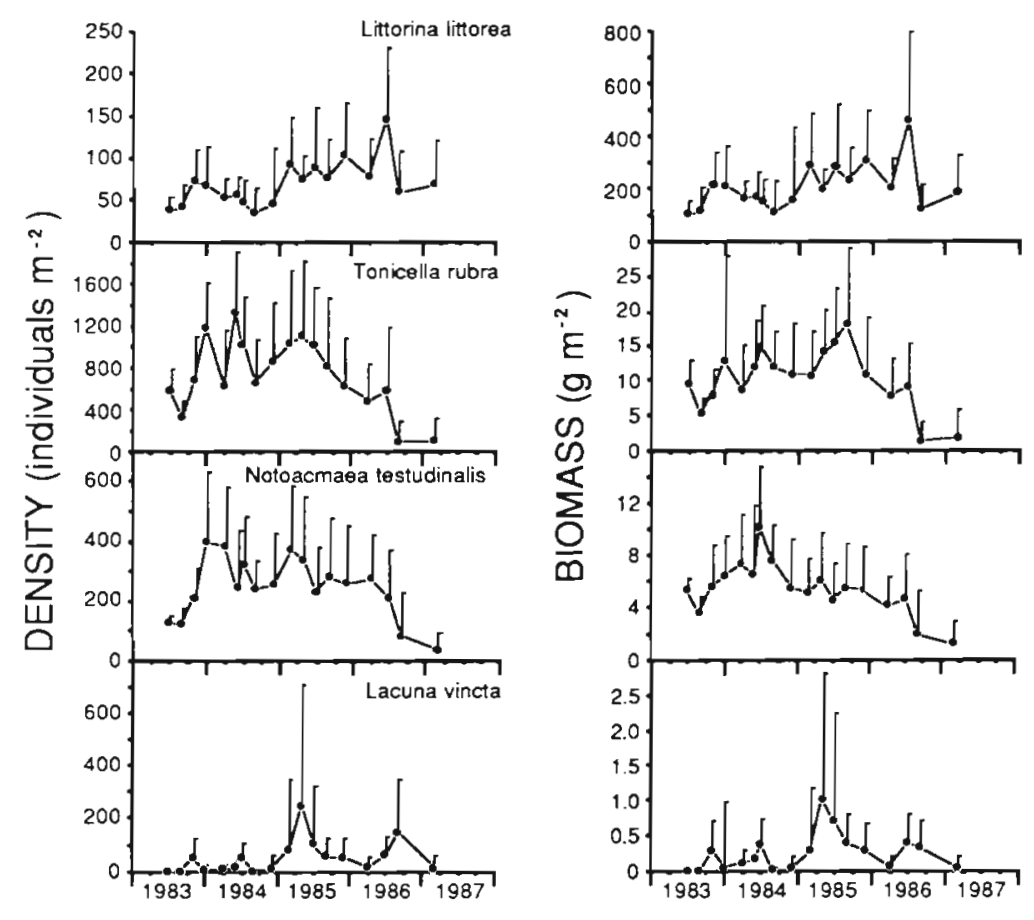

Fig. 6. Mean density and biomass of molluscan grazers (Littorina littorea, Tonicella rubra, Notoacmaea testudinalis, Lacuna vincta) between 1983 and 1987 on the cobble bed at Eagle

Head. Error bars are one standard deviation
Chitons Tonicella rubra and limpets Notoacmaea testudinalis were numerically the most abundant molluscan grazers (Fig. 6). Mean densities ranged from 322 to 1311 ind. $\mathrm{m}^{-2}$ for chitons, and from 121 to 396 ind. $\mathrm{m}^{-2}$ for limpets, between June 1983 and June 1986. However, due to their small size (Figs. 8 and 9), biomass densities of chitons ( 5 to $18 \mathrm{~g} \mathrm{~m}^{-2}$ ) and limpets ( 4 to $10 \mathrm{~g} \mathrm{~m}^{-2}$ ) were 1 to 2 orders of magnitude less than that of periwinkles (Fig. 6). Density and biomass of chitons and limpets did not differ significantly among months between September 1983 and June 1986 (SNK test, $\mathrm{p}>0.05$; samples from June and August 1983 were not included in this analysis because they differed in sample unit size) but declined significantly $(\mathrm{p}<0.05$ ) in August 1986 after the period of inundation by an algal mat. After August 1986, surviving chitons and limpets occurred mainly along the southern end of the grid where the bottom was shallower and drift algae did not usually accumulate.

Recently settled chitons and limpets (1 to $2 \mathrm{~mm}$ shell length) appeared annually on the cobbles in October and November from 1983 to 1985 (Figs. 8 and 9). Modal sizes of these cohorts after $1 \mathrm{yr}$ indicate that chitons grew ca $5 \mathrm{~mm} \mathrm{yr}^{-1}$ and limpets ca $8 \mathrm{~mm} \mathrm{yr}^{-1}$; both species reached a maximum size of ca $12 \mathrm{~mm}$ (Figs. 8 and 9). (A larger species of chiton, Tonicella marmorea, was rarely found on the cobbles). Chitons occurred mainly on Lithothamnium, whereas limpets were found almost exclusively on the smooth, unbranched crusts of Clathromorphum and Phymatolithon, or on bare rock. The number of chitons per cobble was positively corre- lated with the surface area of Lithothamnium ( $\mathrm{r}=$ $0.390, \mathrm{n}=492, \mathrm{p} \ll 0.001$ ) but not with the area of smooth corallines and bare rock ( $r=0.004)$. Conversely, the number of limpets per cobble was positively correlated with the surface area of smooth corallines and bare rock $(r=0.298, n=363, p \ll 0.001)$ but not with the area of Lithothamnium ( $\mathrm{r}=-0.001$ ). Differences in the distribution of chitons and limpets among coralline crusts are related to differences in shell morphology and size. Chitons have a polyplacate, articulated shell enabling them to maneuver in the small recesses and between the protruberances of Lithothamnium. (Their cryptic behaviour and deep pink shell, similar in colour to Lithothamnium, rendered chitons exceedingly inconspicuous on this substratum.) Limpets have a rigid monoplacate shell which precluded all but the smallest individuals (1 to $3 \mathrm{~mm}$ ) from the microrefuges of Lithothamnium. Large chitons (including T. marmorea) also were found only on the smoother crusts.

Abundance of the herbivorous snail Lacuna vincta varied seasonally with highest densities (up to 245 ind. $\mathrm{m}^{-2}$ ) occurring in spring and summer (Fig. 6). It was often found on filamentous and fleshy algae. Postmetamorphic individuals are capable of planktonic dispersal, and large numbers occasionally were observed in the water column in summer. Due to its small size (generally $<3 \mathrm{~mm}$ shell length) the average biomass of $L$. vincta never exceeded $1 \mathrm{~g} \mathrm{~m}^{-2}$.

Amphipods fluctuated in abundance with no clear temporal pattern. Amphipod density generally was 


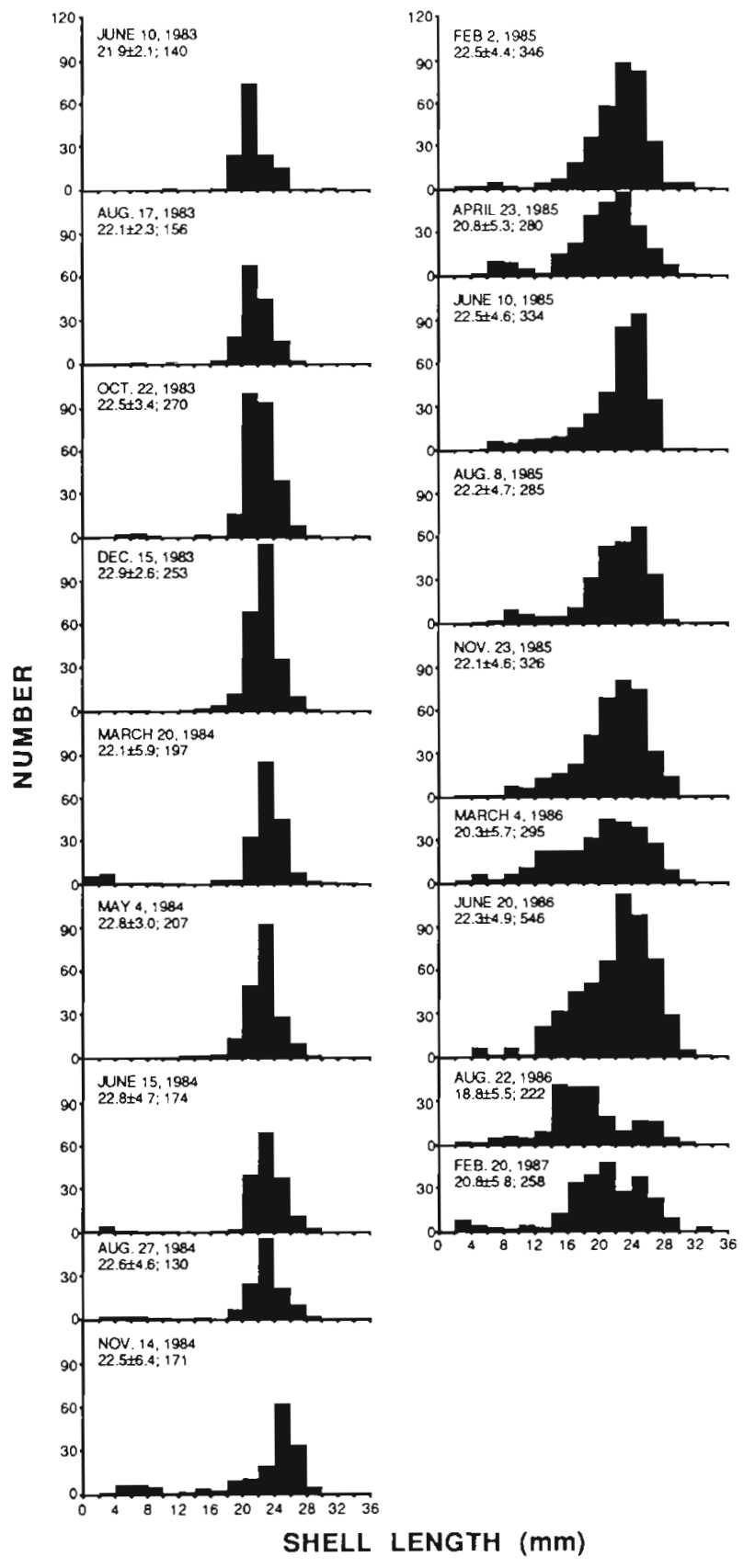

Fig. 7. Littorina littorea. Size-frequency distributions of periwinkles between 1983 and 1987 on the cobble bed at Eagle Head. Data are mean \pm SD shell length and sample size

$<40$ ind. $\mathrm{m}^{-2}$ although ca 100 ind. $\mathrm{m}^{-2}$ were recorded in December 1983 and August 1986. Due to their small size (generally $<10 \mathrm{~mm}$ in body length; mean individual dry weight $=1.35 \mathrm{mg}$ ), mean biomass of amphipods never exceeded ca $0.1 \mathrm{~g} \mathrm{~m}^{-2}$. Amphipods were not separated by species during sample sorting, but subsequent identification of voucher specimens indicated that the majority were Ampithoe rubricata. Other species of amphipods included Melita dentata

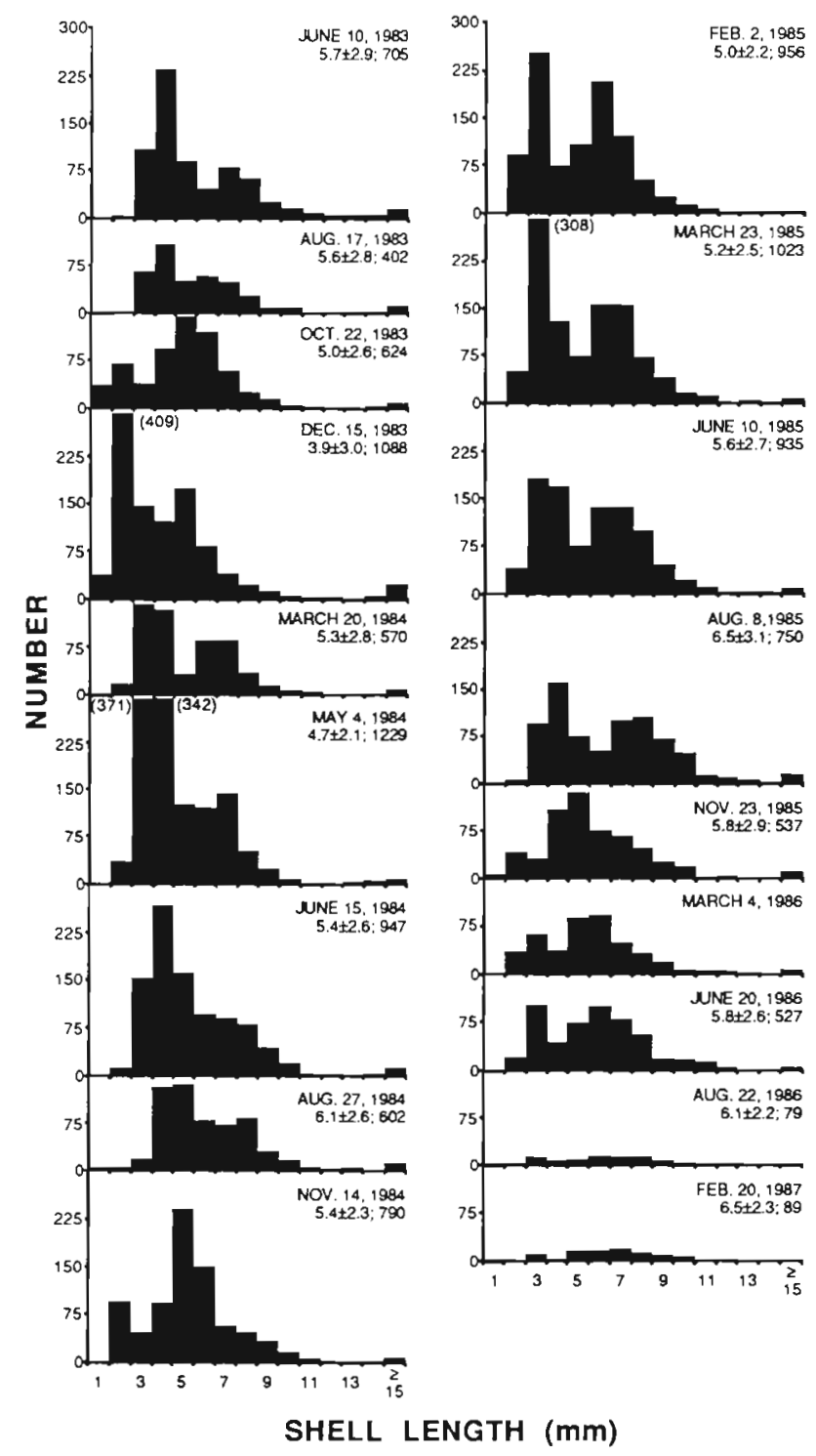

Fig. 8. Tonicella rubra. Size-frequency distributions of chitons between 1983 and 1987 on the cobble bed at Eagle Head. Data are mean \pm SD shell length and sample size; frequency given in parentheses where it exceeds the bounds of the graph

and Corophium simile. The isopod Iodotea baltica occurred sporadically in quadrat samples, usually at densities $<10$ ind $\mathrm{m}^{-2}$. Isopod abundance peaked briefly in August 1986 (141 ind. $\mathrm{m}^{-2}$ ) due to an influx of newly-recruited individuals averaging only $5( \pm 1) \mathrm{mm}$ in body length.

\section{Suspension feeders}

Juvenile mussels Modiolus modiolus and Mytilus edulis were rare on the cobble bed before the sea urchin die-off but increased markedly in abundance 

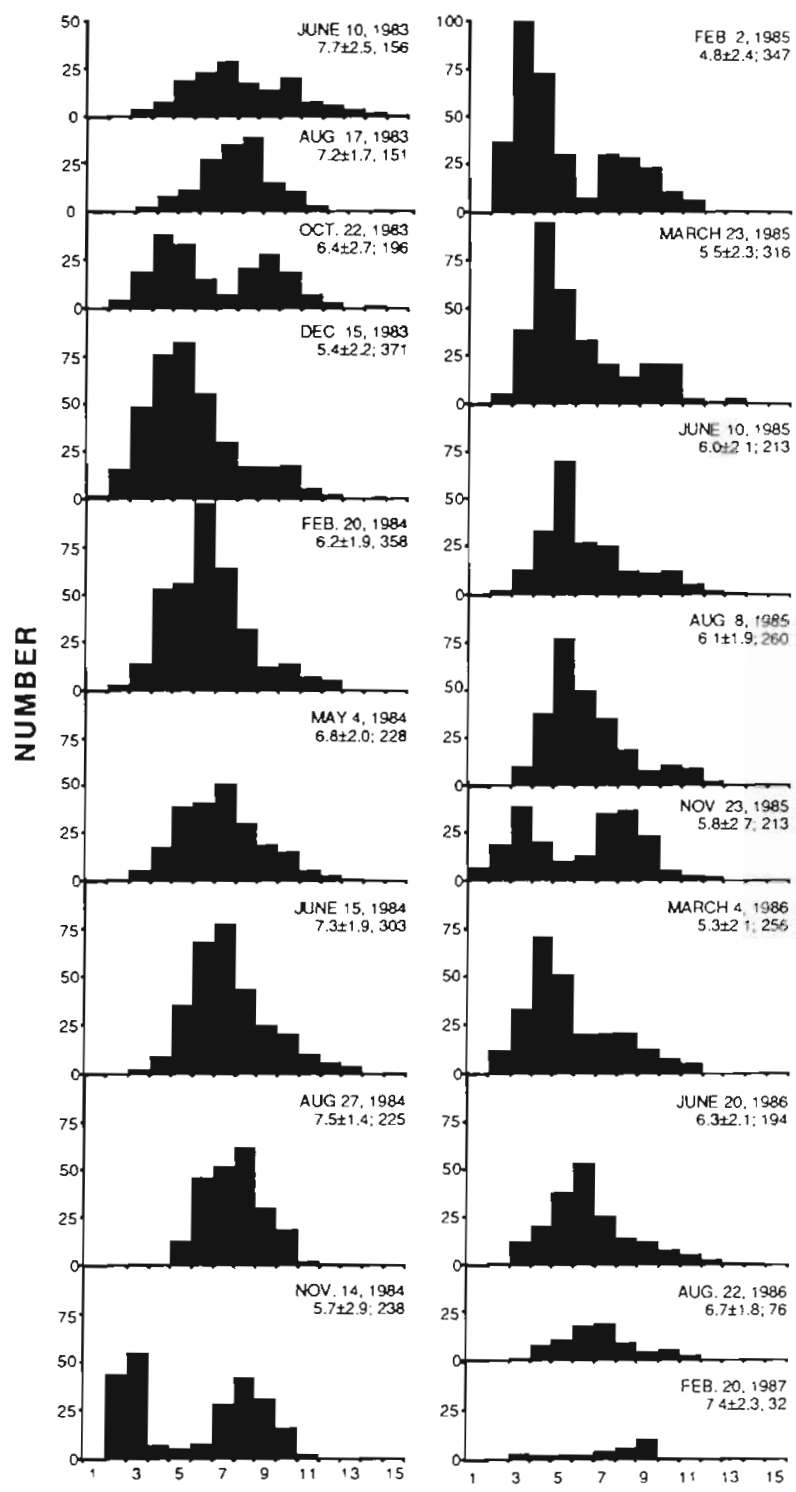

SHELL LENGTH $(\mathrm{mm})$

Fig. 9. Notoacmaea testudinalis. Size-frequency distributions of limpets between 1983 and 1987 on the cobble bed at Eagle

Head. Data are mean \pm SD shell length and sample size

thereafter (Fig. 10). Mussel density fluctuated widely in successive years with peaks between 200 and 250 ind. $\mathrm{m}^{-2}$ (ca $2 \mathrm{~g} \mathrm{~m}^{-2}$ ). It was impractical to determine the identity of most of these small mussels, which generally were $<5 \mathrm{~mm}$ in shell length (mean $\pm \mathrm{SD}: 4.3 \pm 8.1$ ), and the 2 species were pooled. Larger mussels (which could be identified by eye) were mainly $M$. modiolus. Juvenile mussels occurred primarily on. Lithothamnium, particularly between the short branches of this crust. Adults of M. modiolus and $M$. edulis 130 to $90 \mathrm{~mm}$ in shell length) were rare and buried among the cobbles. When they did occur in samples they accounted for most of the mussel biomass. Small clams Hiatella arctica (mean shell length: $6.9 \pm 5.3 \mathrm{~mm}$ ), and jingle shells Anomia sp. $(4.4 \pm 1.9 \mathrm{~mm})$ also were rare prior to the sea urchin die-off. Unlike mussels, however, densities of these species in successive years generally remained low $\left(<10\right.$ to 20 ind. $\mathrm{m}^{-2}$ ) (Fig. 10). (Hiatella arctica, also inhabited cryptic pockets beneath thick crusts of Lithothamnium, but these endolithic individuals were not sampled.) The gastropod Crepidula fornicata also occurred at low density but grew larger (mean shell length. $18.2 \pm 7.6 \mathrm{~mm}$ ) than the bivalves, and accounted for much of suspension-feeder biomass. Small brittle stars Ophiopholis aculeata (generally $<3 \mathrm{~mm}$ in disc diameter) were found beneath the surface layer of cobble in very low numbers $\left(<4\right.$ ind. $\mathrm{m}^{-2}$ ) (Fig. 10). Sea anemones Metridium senile and an unidentified tunicate, sponge and bryozoan were among the other rare species of suspension feeders recorded in only one or a few quadrat samples during the study.

None of the molluscan suspension-feeders (with the possible exception of Hiatella arctica) declined in abundance following prolonged inundation by an algal mat in summer 1986; however, brittle stars virtually disappeared from the cobble bed.

\section{Predators and scavengers}

There were no clear trends in the abundances of predators/scavengers which could be related either to the mass mortality of sea urchins or to the period of inundation by an algal mat. Crustaceans were the most common members of this functional group. Hermit crabs Pagurus acadiensis, (mean carapace length. $8.7 \pm$ $4.0 \mathrm{~mm}$ ) showed consistent seasonal fluctuations in abundance, reaching densities of 13 to 20 ind. $\mathrm{m}^{-2}$ (2 to $4 \mathrm{~g} \mathrm{~m}^{-2}$ ) each spring (Fig. 11). Rock crabs Cancer irroratus, ranging from 3 to $65 \mathrm{~mm}$ in carapace width (mean. $16.9 \pm 15.1 \mathrm{~mm}$ ), generally occurred at densities $<5$ ind $\mathrm{m}^{-2}\left(5 \mathrm{~g} \mathrm{~m}^{-2}\right)$ in quadrat samples (Fig. 11). Only 1 or 2 specimens of Jonah crabs Cancer borealis. green crabs Carcinus maenas, or juvenile lobsters Homarus americanus ( $<5 \mathrm{~mm}$ carapace length) were recorded (in quadrat samples) during the entire study. Lobsters (> $10 \mathrm{~mm}$ ) and crabs (usually $C$. irroratus, rarely $C$. borealis) were consistently abundant and active in the summer and fall, when up to 22 and 35 individuals respectively, were recorded in the sampling grid (Table 3).

Whelks Buccinum undatum, ranging from 3 to $58 \mathrm{~mm}$ in shell length (mean: $30.6 \pm 15.6 \mathrm{~mm}$ ) and small sea stars Asterias vulgaris (mean arm radius: $10.4 \pm 6.3$ $\mathrm{mm}$ ) usually occurred at densities of 1 to 2 ind. $\mathrm{m}^{-2}$ (Fig. 11). Only 3 small specimens of another sea star, 
Fig. 10. Mean density and biomass of suspension feeders (juvenile mussels: Modiolis modiolis, Mytilus edulis; Hiatella arctica; Crepidula fornicata; Anomia sp.; Ophiopholis aculeata) between 1983 and 1987 on the cobble bed at Eagle Head. Error bars are one standard deviation
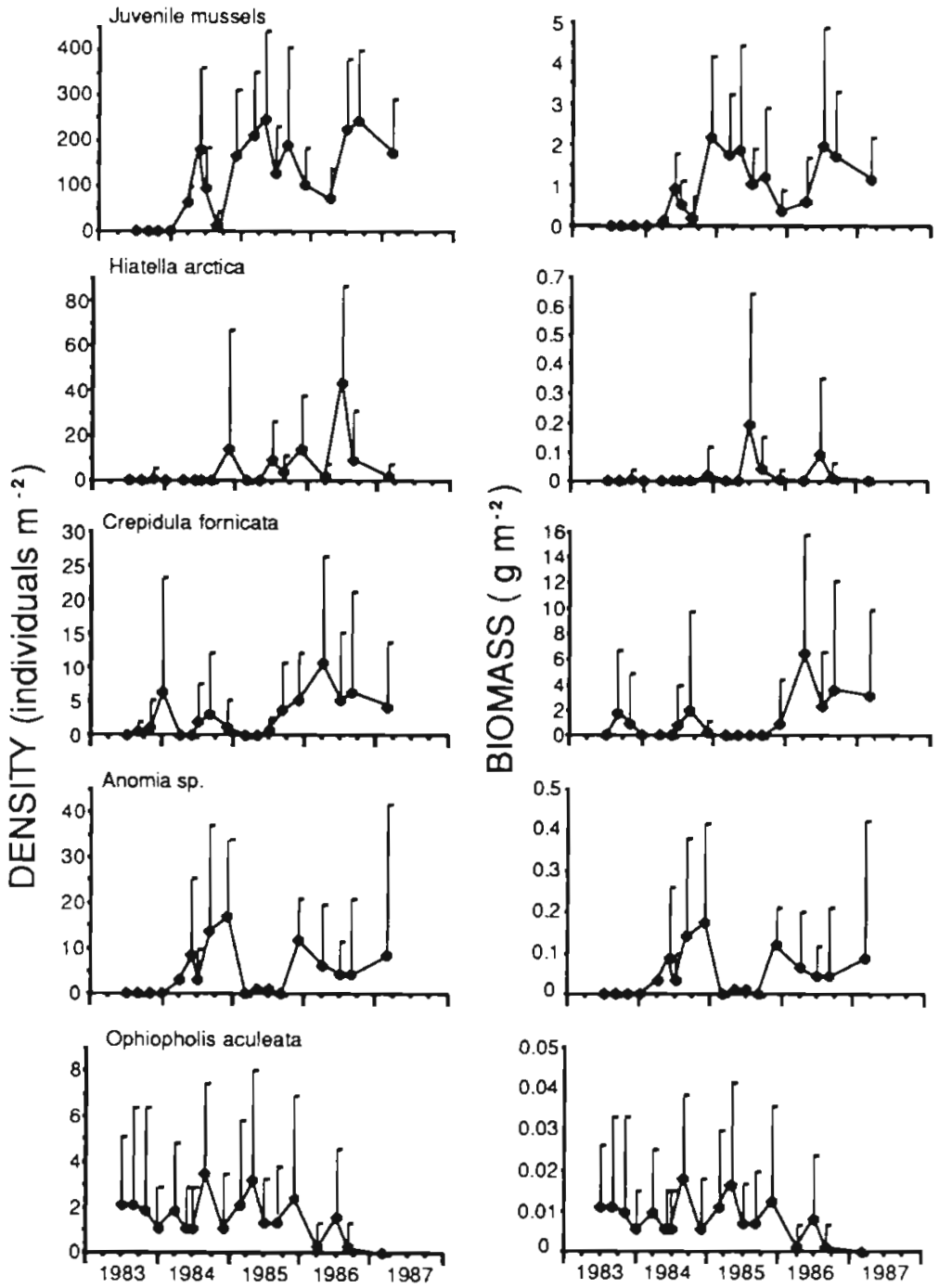

Henricia sanguinolenta, were found during the study. Scale worms Harmathoe fragilis, H. imbricata and Lepidonatus squamatus were the only conspicuous polychaetes on cobbles (mean body length: $15.9 \pm 6.9$ mm, all species combined), occurring at densities ranging from 1 to 16 ind. $\mathrm{m}^{-2}$ (Fig. 11). Another polychaete, Nereis pelagia, occurred in cryptic pockets beneath crusts of Lithothamnium but was not enumerated in quadrat samples.

Fish were uncommon in the study area (although no observations were made at night). Adult sculpins Mxyocephalus octodecemspinosis appeared sporadically, but only one individual was recorded in surveys of the study grid. One juvenile sculpin and 2 small rock gunnels Pholis gunnellus were sampled in quadrats. Juvenile winter flounder Pseudopleuronectes americanus were occasionally observed in the spring, but none were recorded in quadrat samples or grid surveys. Schools of pollack Pollachius virens visited in the study area in summer. A large wolffish Anarhichas lupus was seen once.

Macroalgal-herbivore assemblages on the boulder ridge and on other cobble beds

The boulder ridge at Eagle Head, like the cobble bed which it bordered, was dominated by Strongylocentrotus droebachiensis until the die-off of sea urchins in the fall of 1983. Rock size on the ridge ranged from cobbles to boulders several decimeters in length. The rocks were largely encrusted with coralline algae (mainly Phymatolithon and Clathromorphum) and denuded of macroalgae.

Following the die-off, marcoalgal biomass increased much more rapidly on the ridge than on the adjacent cobble bottom, due mainly to the growth of large, canopy-forming kelps. Mean algal biomass on the 

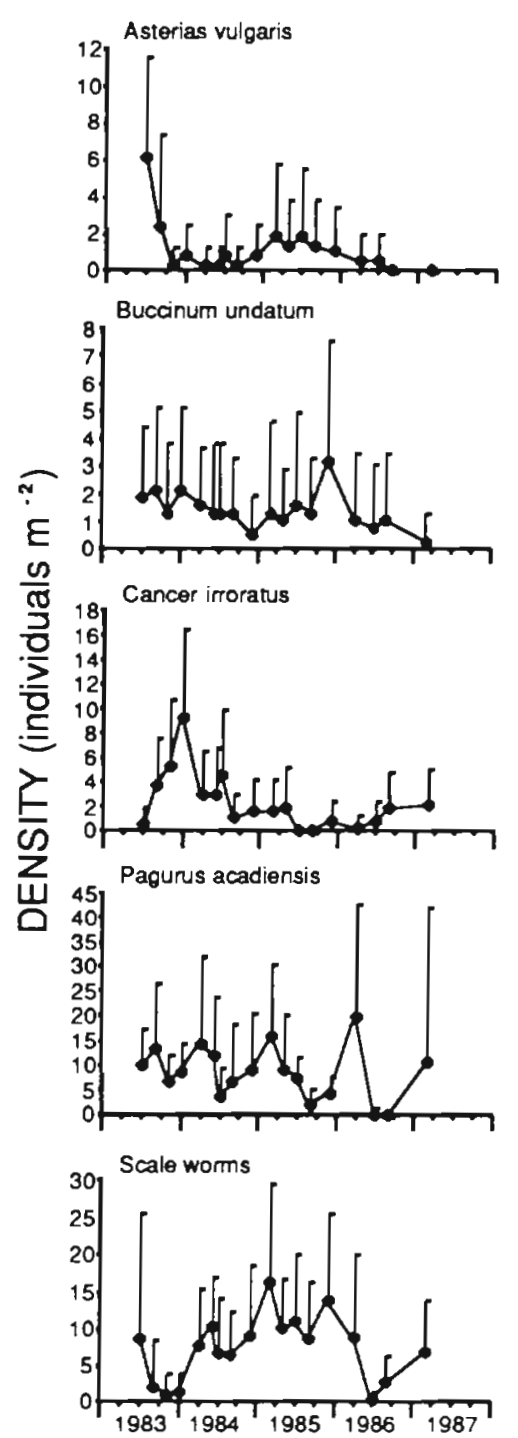
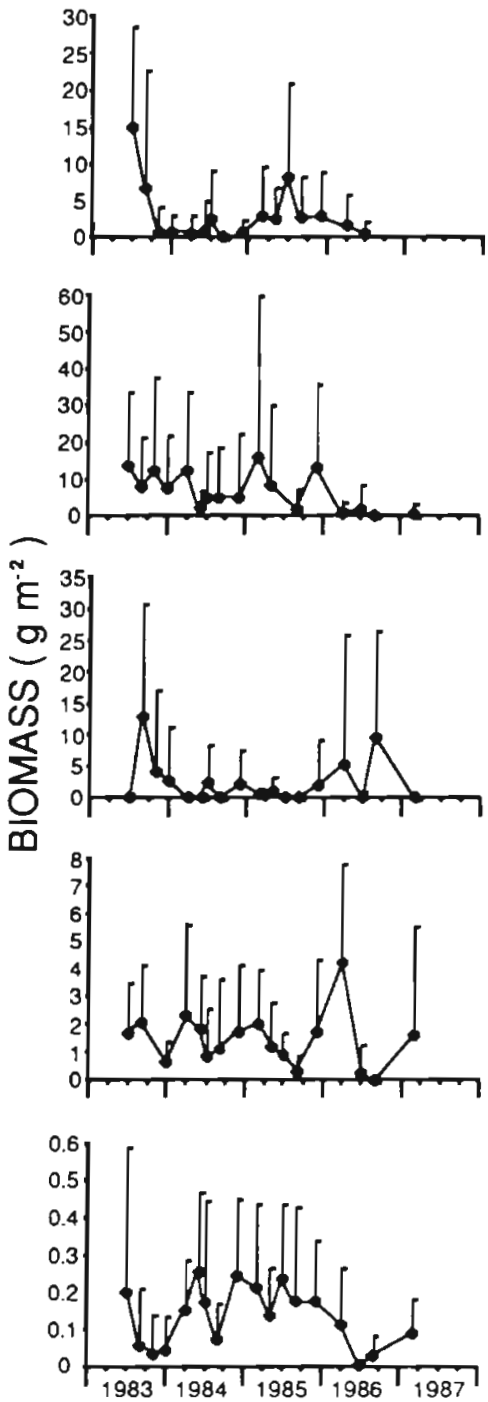

Fig. 11. Mean density and biomass of predators/ scavengers (Pagurus acadiensis; Cancer irroratus, Asterias vulgaris; Buccinum undatum; scale worms: Harmathoe, Lepidonatus) between 1983 and 1987 on the cobble bed at Eagle Head. Error bars are one standard deviation ridge in early June $1987\left(2776.7 \mathrm{~g} \mathrm{~m}^{-2}\right)$ was about 60 times higher than that on the cobble bed in late February 1987 (46.7 $\mathrm{g} \mathrm{m}^{-2}$ ) (Fig. 12, Appendix 1). Laminaria digitata and $L$. longicruris were the dominant kelps on the ridge in June 1987 Saccorhiza dermatodea, an annual kelp, was less abundant at this time and consisted mainly of young plants; however, it increased in size and abundance by late summer and fall. to become a major component of canopy cover (pers. obs.). Fucus evanescens also was abundant and attained large size on the boulders. Together, kelps and Fucus formed a dense canopy which accounted for $83 \%$ of the total macroalgal biomass on the ridge (Fig. 12) In contrast, kelps were rare on the cobble bed and Fucus consisted of small, sparsely distributed plants: Fucus biomass on cobbles was only $5 \%$ of that on the ridge, kelp biomass was a mere $0.1 \%$ (Appendix 1). Corallina officinalis and Chondrus crispus formed dense patches of turf beneath the kelp and Fucus canopy on the ridge (Appendix 1). Filamentous brown algae (Scytosiphon sp., Desmarestia viridis) and red algae (Polysiphonia harveyi, Rhodomela confervoides) also occurred in the understory. On the cobble bed, the biomass of $C$. crispus was about $25 \%$ of that on the ridge, C. officinalis was rare and filamentous algae were virtually absent (Appendix 1).

Juveniles of Strongylocentrotus droebachiensis were found on the boulder ridge between May 1986 and June 1987 (Fig. 5b, Table 4). Their numbers progressively decreased as they increased in size (Fig. 5b). They presumably were of the same cohorts which settled in the cobble bed in 1983-1984 (Fig. 5a), as their size is consistent with that of 2 to 3 yr-old sea urchins (Raymond \& Scheibling 1987). Sea urchins on both the cobble bed and the boulder ridge were cryptic, occurring in the interstices and on the undersides of rocks. 
Table 3. Numbers of large crabs (Cancer irroratus, C. borealis) and lobsters (Homarus americanus) observed in the $250 \mathrm{~m}^{2}$ study grid

\begin{tabular}{|lcc|}
\hline Sampling date & Cancer spp & H. americanus \\
\hline 15 Dec 1983 & 2 & 0 \\
20 Mar 1984 & 0 & 0 \\
4 May & 0 & 0 \\
15 Jun & $n^{d}$ & $n m$ \\
27 Aug & 4 & 16 \\
11 Nov & 7 & 0 \\
23 Apr 1985 & 1 & 0 \\
10 Jun & $n \mathrm{~nm}$ \\
8 Aug & $\mathrm{nm}$ & $n \mathrm{~nm}$ \\
23 Nov & 22 & 1 \\
4 Mar 1986 & 1 & 0 \\
20 Jun & $\mathrm{nm}$ & $\mathrm{nm}$ \\
22 Aug & 19 & 0 \\
2 Feb 1987 & 0 & 0 \\
a nm: not measured due to extensive mats of drift algae \\
which covered the study area. In June and August, crabs \\
and lobsters were particularly abundant and often were \\
observed under algal mats
\end{tabular}

Those on the ridge often held small fragments of drift algae against the test with their tube feet.

Densities of Littorina littorea and Tonicella rubra on the boulder ridge in June 1987 were comparable to those on the cobble bed in February 1987; densities of Notoacmaea testudinalis were 4 times higher on the ridge (Table 4). However, each of these species occurred at much higher densities (up to 146, 1297 and 396 ind. $\mathrm{m}^{-2}$ for periwinkles, chitons and limpets respectively) on the cobble bed prior to mass mortalities in the summer of 1986 (Fig. 6).

Among the 3 other cobble beds sampled in May 1987, non-calcareous macroalgae occurred in only 2 locations, Coffin Island and McNutt Island (Fig. 12). Mean macroalgal biomass at these sites (49.6 and $38.0 \mathrm{~g} \mathrm{~m}^{-2}$ respectively) did not differ significantly ( $\mathrm{t}$ test, $p>0.50$ ) from that on the cobble bottom at Eagle Head in February 1987 (46.7 $\mathrm{g} \mathrm{m}^{-2}$ ). At each site, Fucus evanescens and Chondrus crispus were the main fleshy
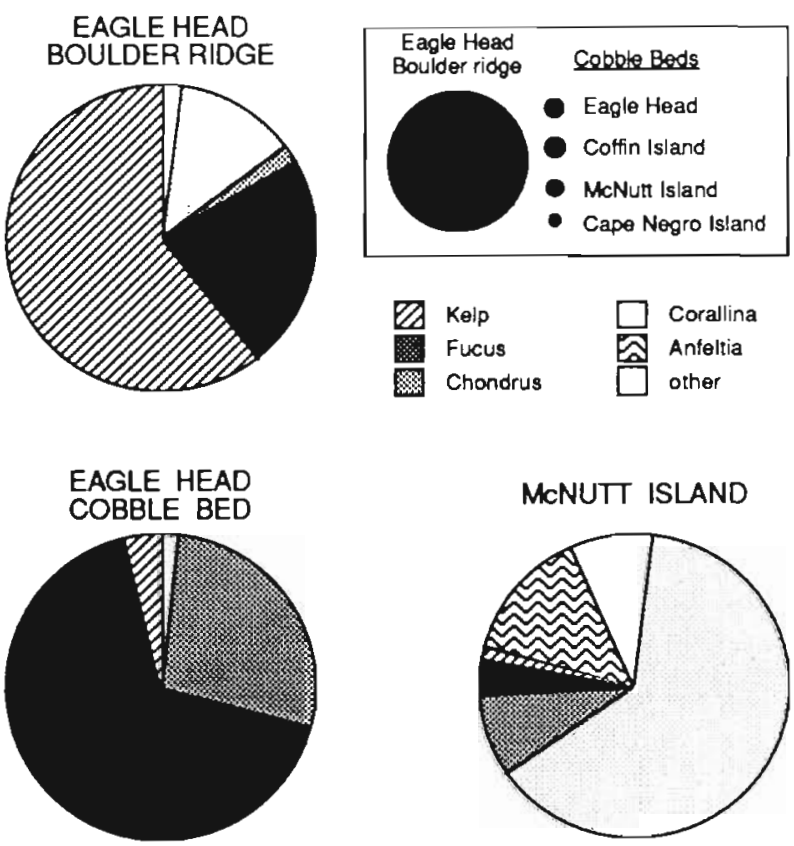

COFFIN ISLAND

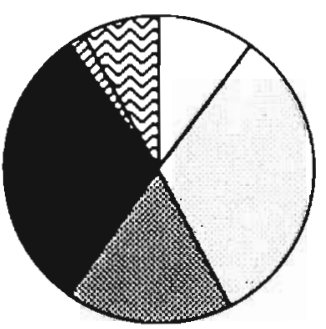

CAPE NEGRO ISLAND

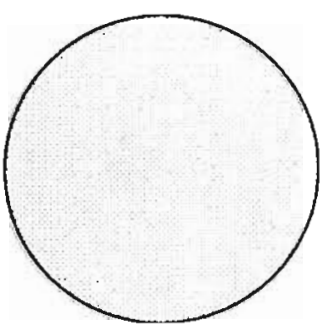

Fig. 12. Algal species composition as percentage of total biomass (dry weight) on the boulder ridge (June 1987) and cobble bed at Eagle Head (February 1987), and on the cobble beds at Coffin Island, McNutt Island and Cape Negro Island (May 1987). Inset: area of each circle is proportional to the total algal biomass at each site

algal species and kelps were rare (Fig. 12). Erect coralline algae (Corallina officinalis) and filamentous red algae (mainly Anfeltia plicata) were major components of algal biomass at Coffin Island and McNutt Island,

Table 4. Mean and standard deviation (in parentheses) density (ind. $\mathrm{m}^{-2}$ ) of major species of grazers on the cobble bed and boulder ridge at Eagle Head and on cobble beds at 3 other sites along the southwestern shore of Nova Scotia in 1987. Data are for 15 random quadrats at each site. Sampling dates: Eagle Head cobble bed, 20 February; Eagle Head boulder ridge, 15 June; Coffin Island, 20 May; McNutt Island, 26 May; Cape Negro Island, 27 May. Quadrat size: $0.25 \mathrm{~m}^{2}$ for Littorina Iittorea and Strongylocentrotus droebachiensis; $0.0625 \mathrm{~m}^{2}$ for Tonicella rubra and Notoacmaea testudinalis

\begin{tabular}{|c|c|c|c|c|c|}
\hline Grazer species & $\begin{array}{c}\text { Eagle Head } \\
\text { (boulders) }\end{array}$ & $\begin{array}{c}\text { Eagle Head } \\
\text { (cobbles) }\end{array}$ & $\begin{array}{l}\text { Coffin } \\
\text { Island }\end{array}$ & $\begin{array}{l}\text { McNutt } \\
\text { Island }\end{array}$ & $\begin{array}{c}\text { Cape Negro } \\
\text { Island }\end{array}$ \\
\hline Littorina littorea & $49(41)$ & $69 \quad(51)$ & 71 (28) & $29 \quad(16)$ & 0 \\
\hline Tonicella rubra & $80(72)$ & $95(203)$ & $64 \quad(42)$ & $500(144)$ & $21 \quad(25)$ \\
\hline Notoacmaea testudinalis & $132(95)$ & $34 \quad(57)$ & $284 \quad(83)$ & $210 \quad(90)$ & $125(92)$ \\
\hline Strongylocentrotus droebachiensis & $17 \quad(26)$ & 0 & 0 & (8) & $344(189)$ \\
\hline
\end{tabular}


but rare at Eagle Head (Fig. 12). It is not known whether detrital mats accumulate in these cobble beds as they did at Eagle Head; we observed only scattered fragments of drift algae during our sampling of these areas in May 1987. Littorina littorea, Tonicella rubra and Notoacmaea testudinalis were abundant at Coffin Island and McNutt Island (Table 4), with densities, in some cases, comparable to those recorded on the cobble bed at Eagle Head prior to the mass mortalities of these species (Fig. 6). Strongylocentrotus droebachiensis was absent at Coffin Island and rare at McNutt Island (Table 4).

The cobble bed at Cape Negro Island was distinct from the other 3 sites: fleshy and filamentous algae were absent (Corallina officinalis was the only erect alga) (Fig. 12) and Strongylocentrotus droebachiensis was extremely abundant (Table 4). The size distribution of sea urchins was polymodal with a primary mode at 12 to $14 \mathrm{~mm}$ and a secondary mode at 30 to $32 \mathrm{~mm}$ (Fig. 5c), indicating successful recruitment of 2 or more cohorts after the sea urchin die-off in the fall of 1983. Notoacmaea testudinalis also was abundant at Cape Negro Island but Tonicella rubra was not, and Littorina littorea was absent (Table 4).

\section{DISCUSSION}

In the wake of mass mortalities of Strongylocentrotus droebachiensis off Nova Scotia, algal succession on boulder and bedrock substrata proceeded rapidly from diatoms and small, fast growing filamentous algae through to large canopy-forming kelps (Miller 1985a, Novaczek \& McLachlan 1986, Scheibling 1986, Johnson \& Mann 1988). Within 2 to $3 y r$, the biomass and composition of these kelp beds (mainly Laminaria longicruris and L. digitata) were similar to those of former, mature beds which preceeded the period of sea urchin dominance ( Novaczek \& McLachlan 1986, Scheibling 1986). The establishment of erect macroalgae in cobble beds was far more gradual and limited. Moreover, there was no clear succession: Fucus evanescens and Chondrus crispus were consistently the most abundant erect macroalgal species on the cobble bed at Eagle Head, although both species consisted of small and sparsely-distributed plants. Crustose corallines remained the predominant algal type on cobbles throughout the study. There was no detectable change in the relative cover of any of the coralline genera after the sea urchin die-off, suggesting that sea urchin grazing had little or no impact on intercrust competition (Paine 1984, Steneck 1986) This may be because sea urchins, although abundant, fed mainly on drift algae deposited in the cobble bed (Scheibling \& Stephenson 1984). Large, attached kelps (Laminaria longicruris, $L$. digitata and Saccorhiza dermatodea) were virtually absent on the cobbles, but formed a dense canopy on the adjacent boulder ridge after the die-off. Davis \& Wilce (1987) also found that crustose algae and turfs of small filamentous and foliose species dominated the macroflora of a cobble bed off Massachusetts (USA) while the surrounding rocky outcrops supported a luxuriant kelp community.

Similarities in algal biomass and composition among cobble beds suggest common elements in the processes influencing algal colonization, growth and survival, which differ from those operating on boulder and bedrock substrata. Previous studies have shown that physical disturbance may be a key determinant of macroalgal composition and abundance on cobbles and small boulders in intertidal (Osman 1977, Sousa 1979a,b, Littler \& Littler 1984) and subtidal (Lieberman et al. 1979, 1984) habitats. Gradual overturning of small to moderately sized cobbles probably does occur at Eagle Head (particularly in the shallower and gently sloping regions which abut the boulder ridge) as indicated by the presence of live coralline algae on the undersides of many of these cobbles. Larger cobbles with greater inertia are much less likely to be overturned; only their upper surfaces are encrusted with corallines. In general, the cobbles at Eagle Head were closely packed in a relatively stable matrix. We observed minimal displacement (generally $<0.5 \mathrm{~m}$ ) of marked cobbles at Eagle Head, even after periods of 9 to 12 mo (Scheibling unpubl.). When 'holes' were made in the bed by burrowing lobsters or by our removal of cobble samples, they were gradually refilled over a period of weeks by the lateral movement of the surrounding cobbles. There was no evidence (e.g. conspicuous abrasion and damage to corallines and erect algae) that cobbles were rapidly tumbled or scattered by wave action even after heavy winter storms (cf. Lieberman et al. 1979).

Grazing by other herbivores also can influence the composition and rate of establishment of macroalgae following mass mortalities of sea urchins (Carpenter 1985, 1988). Chitons Tonicella rubra, limpets Notoacmaea testudinalis and periwinkles Littorina littorea are extremely abundant in Nova Scotian cobble beds and may be particularly important in limiting algal recruitment. Chitons and limpets rasp the surface (epithallial) layers of corallines, ingesting epiphytic microalgae including the propagules of macroalgae (Steneck 1982). Periwinkles teed on microalgal films and small filamentous and foliose macroalgae (Menge 1976. Lubchenco 1978). Germlings of Fucus and Chondrus also are consumed, although once these plants attain a length of 3 to $5 \mathrm{~mm}$ they are relatively immune to periwinkle grazing (Lubchenco 1980). Experiments at Eagle Head showed that exclusion of chitons, limpets and periwinkles from cobbles resulted in colonization 
by a variety of fast-growing filamentous algae that were usually rare or absent on the cobble bed (Scheibling unpubl.). After the demise of sea urchins, however, there were no other herbivores capable of effectively consuming large fleshy macroalgae either growing on the cobbles or deposited as drift. Population outbreaks of Lacuna vincta have been shown to cause extensive damage to Fucus (Thomas \& Page 1983) and Laminaria (Fralick et al. 1974, Johnson \& Mann 1986) in eastern Canada and the Gulf of Maine; however, these snails occurred in comparatively low numbers during our study at Eagle Head.

As plants (particularly large fleshy perennials like Fucus and kelps which escape in size from molluscan grazers) grow up on cobbles their drag increases. Once a plant attains a certain critical size (depending on the morphology of the plant, the mass of the cobble to which it is attached, and the velocity of the surrounding water) it may be displaced, together with the cobble to which it is attached, by wave action. Bivalves with kelps or other large macroalgae growing on their shells are detached in the same way (Witman \& Suchanek 1984, Black \& Peterson 1987, Witman 1987). At Eagle Head, we observed kelp-bearing rocks ('drifters') up to ca $30 \mathrm{~cm}$ in length being transported across the cobble bed and deposited in the deeper, muddy regions of the basin where the plants eventually were inundated by sediment and decomposed. Most 'drifters' probably originate on the surrounding boulder ridge where kelps and Fucus growing on cobbles and small boulders are dislodged by the battering force of the waves. However, the same process also may limit the size of macroalgae in the cobble bed, and may contribute to the disparity in algal assemblages on cobbles relative to more stable, boulder and bedrock substrata.

These observations suggest that grazing by small but abundant molluscan herbivores is an important agent of mortality in the early stages of plant life history and community development, when it acts as a biological filter, whereas physical disturbance becomes increasingly more important in latter stages, when it limits the kinds and sizes of plants which can grow up on cobbles. Thus, one might predict that the plant community at Eagle Head would evolve toward a low-lying algal bed or turf, with Fucus evanescens and Chondrus crispus persisting as the dominant forms to the exclusion of large kelps. As plant densities increased, competitive interactions and periodic disturbances (e.g. displacement of large plants as drifters) would become increasingly more important as determinants of species diversity and patch dynamics, as has been shown in previous studies (e.g. Dayton 1971, Sousa 1979a, Dayton et al. 1984, Johnson \& Mann 1988). However, the accumulation of mats of drift algae, resulting in mass mortalities of both plants and animals, may arrest the process of community development and ultimately reverse its course. Thus, the transition from a sea urchin-dominated, coralline algal community to a fleshy macroalgal bed may not be realized, but rather redirected toward a detritus-based decomposer community associated with drifting algal mats. Whether this is an isolated phenomenon, related to local hyrodynamic conditions at Eagle Head, or of more general significance in shallow subtidal communities along this coast is unknown.

Substantial recovery of sea urchin populations after mass mortality, as was the case at Cape Negro Island, may preclude colonization of fleshy macroalgae or result in destructive grazing of recently established seaweeds. Such recovery may be contingent upon intensive recruitment events that swamp predatory controls (Scheibling 1986, Hart \& Scheibling 1988). At Eagle Head, Strongylocentrotus droebachiensis that recruited to the cobble bed after the die-off were decimated in the fall of 1984, presumably by predators (rock crabs and lobsters were particularly abundant and active at that time) since no further outbreaks of disease were recorded after 1983. Sea urchins from the same cohorts persisted on the adjacent boulder ridge and under small boulders experimentally transplanted to the cobble bed from the adjacent boulder ridge (Scheibling unpubl.). While the interstices of cobbles may provide refuges for sea urchins at an early juvenile stage $(<10 \mathrm{~mm})$, they eventually outgrow these spaces and require larger rocks or crevices for protection from predators (Scheibling unpubl.).

Small-scale structural complexity of cobble beds also may account for the abundance of small molluscs and other invertebrates in these habitats (McGuinness \& Underwood 1986). Densities of chitons and limpets on cobble beds in this study were generally 1 or 2 orders of magnitude higher than those recorded on stable rocky substrata in eastern Canada (Himmelman et al. 1983, Michaud 1986) and the Gulf of Maine (Steneck 1982, Logan et al. 1984, Witman 1985, Ojeda \& Dearborn 1989). Different morphologies of coralline crust provide different microhabitats for the small plants and animals which settle and grow upon them. Tonicella rubra, juveniles of Modiolus modiolus and Mytilus edulis, and Fucus evanescens occurred primarily on Lithothamnium. The rugose topography of this crust may influence the deposition and adhesion of larvae and algal propagules (Harlin \& Lindberg 1977, Wethey 1986) and/or provide microrefuges from predators/grazers (Steneck 1986).

Populations of the herbivorous molluscs Tonicella rubra, Notoacmaea testudinalis and Littorina littorea did not increase significantly after the sea urchin dieoff at Eagle Head, nor was there any evidence of a functional response in terms of increased growth rate 
or body size in these species. The apparent lack of competitive release may be due to dietary differences between Strongylocentrotus droebachiensis, which fed largely on drift algae, and these molluscs, which graze microalgal films and coralline crusts. High population densities of herbivores were maintained by annual ( $T$. rubra, N. testudinalis) or continuous (L. littorea) recruitment to the cobble bed between 1983 and 1985. However, increased accumulation of drift algae by 1986 probably limited further recruitment of these species (and others) and caused mass mortalities due to anoxia. Drifting algal mats have been shown to have similar adverse effects on recruitment (Olafsson 1988) and species abundance (Thrush 1986) in soft bottom communities.

The abundance of juvenile mussels Modiolus modiolus and Mytilus edulis at Eagle Head increased markedly after the sea urchin die-off, although densities fluctuated widely within years. Strongylocentrotus droebachiensis is known to prey on small mussels (Himmelman et al. 1983, Briscoe \& Sebens 1988) which may explain the paucity of these species and other small bivalves (Hiatella arctica, Anomia sp.) prior to the die-off. A heavy recruitment of $M$. edulis also was observed following experimental removal of sea urchins in the St. Lawrence Estuary (Himmelman et al. 1983). In the absence of sea urchins, predation on juvenile mussels by rock crabs (Drummond-Davis et al. 1982, Scheibling 1984a), lobsters (Elner \& Campbell 1987) and starfish (Menge 1979) may account for the low numbers of adult mussels in the cobble bed. There were no clear trends in the abundance of these predators, or of scavenging whelks, hermit crabs and scale worms, following the sea urchin die-off. Predatory fish such as wolffish Anarhichas lupus and cunner Tautogolabrus adspersus, which are important consumers of mussels, sea urchins and other small invertebrates elsewhere in eastern Canada and the Gulf of Maine (Edwards et al. 1982, Green et al. 1984, Witman 1985, Johnson \& Mann 1986, Keats et al. 1986), were rare or absent throughout the study.

Acknowledgements. We thank Greg Croft for his expert diving assistance in the field, and Andrea Griswold, Deborah Roberts-Regan, Susan Douglas, Tracy Willar, and Stewart Johnson for their meticulous assistance with the tedious but all-important work of sample processing and data recording. We also thank Tony Chapman and Carolyn Bird for indentifying many of the algal species, Terry Parker for identifying the amphipods, and Pat Pocklington for identifying the polychaetes. The research was funded by an NSERC Operating Grant to RES. The manuscript was written while RES held a Visiting Fellowship in the Department of Zoology, The University of Western Australia. Bob Black, Annamarie Hatcher and Bruce Hatcher provided valuable comments on an earlier draft.

\section{LITERATURE CITED}

Black, R., Peterson, C. H. (1987). Biological vs. physical explanations for the non-random pattern of host occupation by a macroalga attaching to infaunal bivalve molluscs. Oecologia (Berl.) 73: 213-221

Bourdouresque, C. F., Nedelec, N., Shepard, S. A. (1981). The decline of a population of the seaurchin Paracentrotus lividus in the Bay of Part-Cros (Var, France). Rapp. P.-v. Réun. Commn int. Explor. scient. Mer Méditerr 27: 233-244

Briscoe, S. C., Sebens K. P. (1988). Omnivory in Strongylocentrotus droebachiensis (Muller) (Echinodermata: Echinoidea): predation on subtidal mussels. J exp. mar. Biol. Ecol. 115: 1-24

Carpenter, R. C. (1985). Sea urchin mass mortality: effects on reef algal abundance, species composition and metabolism, and other coral reef herbivores. Proc. Fifth Int. Coral Reef Congress 4: 53-60

Carpenter, R. C. (1988). Mass mortality of a Caribbean sea urchin: immediate effects on community metabolism and other herbivores. Proc. natn. Acad. Sci. USA 85:511-514

Davis, A. N., Wilce, R. T. (1987). Floristics, phenology, and ecology of the sublittoral marine algae in an unstable cobble habitat (Plum Cove, Cape Ann, Massachusetts, USA). Phycologia 26: 23-34

Dayton, P. K. (1971). Competition, disturbance, and community organization: the provision and subsequent utilization of space in a rocky intertidal community. Ecol. Monogr. 41: $351-389$

Dayton, P. K., Currie, V., Gerrodette, T., Keller, B. D., Rosenthal, R., Ven Tresca, D. (1984). Patch dynamics and stability of some California kelp communities. Ecol. Monogr. 54: 253- 289

Drummond-Davis, N. C., Mann, K. H., Pottle, R. A. (1982). Some estimates of population density and feeding habits of the rock crab. Cancer irroratus, in a kelp bed in Nova Scotia. Can. J. Fish. Aquat. Sci. 39: 636-639

Edwards, D. C., Conover, D. O., Sutter III, F. (1982). Mobile predators and the structure of marine intertidal communities. Ecology 63: 1175-1180

Elner, R. W., Campbell, A. (1987). Natural diets of lobster Homarus americanus from barren ground and macroalgal habitats off southwestern Nova Scotia, Canada. Mar. Ecol. Prog. Ser. 37: 131.-140

Fralick, R. A., Turgeon, K. W., Mathieson, A. C. (1974). Destruction of kelp populations by Lucuna vincta (Montagu). Nautilus 88: 112-114

Green, J. M., Martel, G., Martin, D. W (1984). Comparisons of the feeding activity and diets of male and female cunners Tautogolabrus adspersus (Pices: Labridae). Mar. Biol. 84: 7-11

Harlin, M. M., Lindberg, J. M. (1977). Selection of substrata by seaweeds: optimal surface relief. Mar. Biol. 32: 33-44

Hart, M. W. Scheibling, R. E. (1988). Heat waves, baby booms, and the destruction of kelp beds by sea urchins. Mar. Biol. 99: 167-176

Himmelman, J. H., Cardinal A., Bourget, E. (1983). Community development following removal of urchins, Strongylocentrotus droehbachiensis, from the rocky subtidal zone of the St. Lawrence Estuary, Eastern Canada. Oecologia (Berl.) 59: 27-39

Hughes, T. P., Reed, D. C., Boyle, M. J. (1987). Herbivory on coral reets: community structure following mass mortalities of sea urchins. J. exp. mar. Biol. Ecol. 113: 39-59

Johns, P. M., Mann, K. H. (1987). An experimental investigation of juvenile lobster habitat preference and mortality 


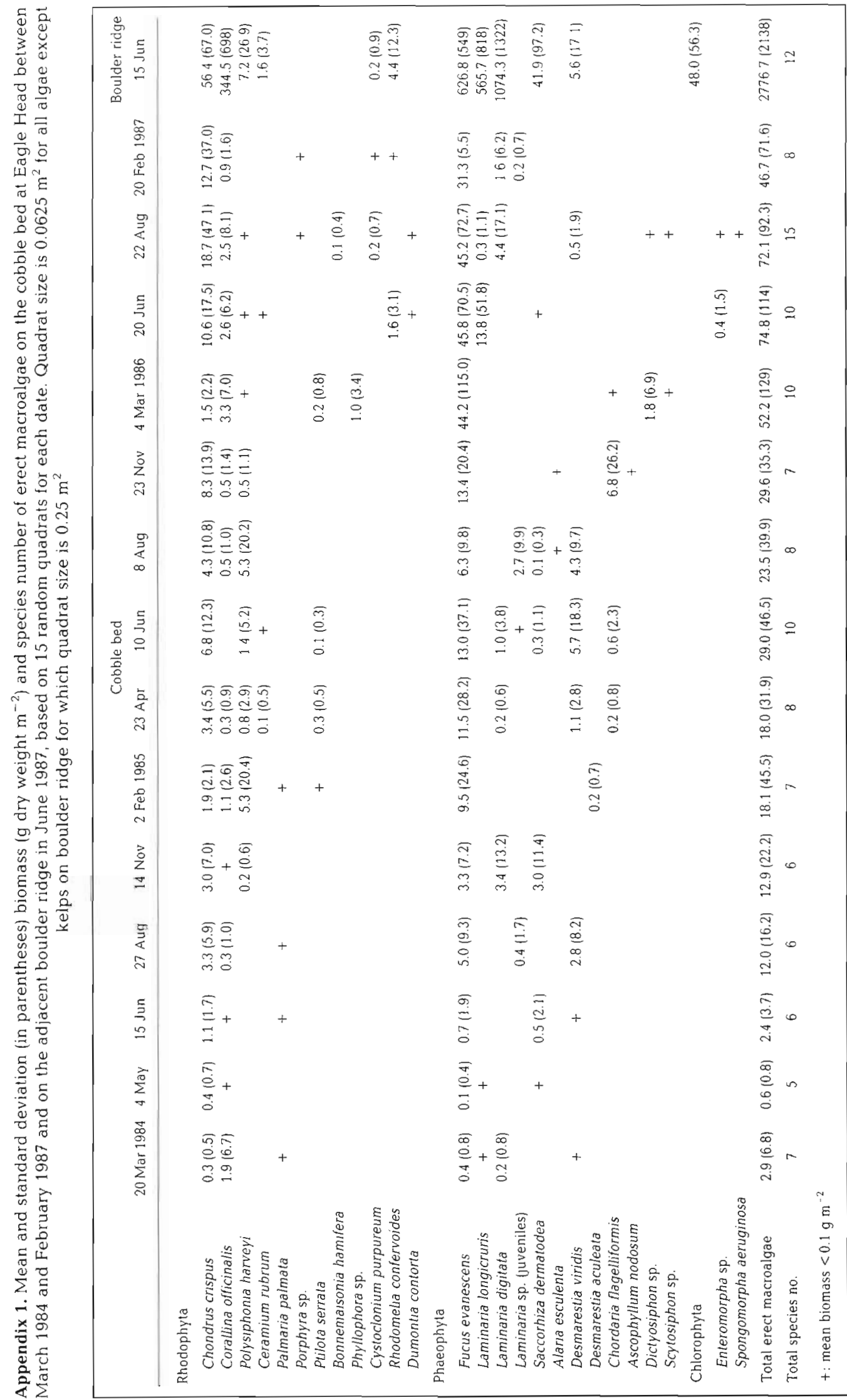


among habitats of varying structural complexity. J. exp. mar. Biol. Ecol. 109: 275-285

Johnson, C. R., Mann, K. H. (1986). The importance of plant defence abilities to the structure of subtidal seaweed communities: the kelp Laminaria longicruris de la Pylaie survives grazing by the snail Lacuna vincta (Montagu) at high population densities. J. exp. mar Biol. Ecol. 97: 231-267

Johnson, C. R., Mann, K. H. (1988). Diversity, patterns of adaptation, and stability of Nova Scotian kelp beds. Ecol. Monogr. 58: 129-154

Jones, C. M., Scheibling, R. E. (1985). Paramoeba sp. (Amoebida, Paramoebidae) as the possible causative agent of sea urchin mass mortality in Nova Scotia. J. Parasit. 71 : $559-565$

Keats, D. W., Steele, D. H., South, G. R. (1986). Atlantic wolffish (Anarhichas lupus L.; Pisces: Anarhichidae) predation on green sea urchins (Strongylocentrotus droebachiensis (O.F. Mull.); Echinodermata: Echinoidea) in eastern Newfoundland Can. J. Zool. 64: 1920-1925

Kinne, O. (ed.) (1980). Diseases of marine animals, Vol. 1. Wiley, Chichester

Lessios, H. A., Robertson, D. R., Cubit, J. D. (1984a). Spread of Diadema mass mortality through the Caribbean. Science 226: $335-337$

Lessios, H. A., Cubit, J. D., Robertson, D. R., Shulman, M. J., Parker, M. R., Garrity, S. D., Levings, S. C. (1984b). Mass mortality of Diadema antillarum on the Caribbean coast of Panama. Coral Reefs 3: 173-182

Levitan, D. R. (1988). Algal-urchin biomass responses following the mass mortality of Diadema antillarum Philippi at St. John. J. exp. mar. Biol. Ecol. 1.19: 167-178

Lieberman, M., John, D. M., Lieberman, D. (1979). Ecology of subtidal algae on seasonally devastated cobble substrates off Ghana. Ecology 60: 1151-1161

Lieberman, M., John, D. M., Lieberman, D. (1984). Factors influencing algal species assemblages on reef and cobble substrata off Ghana. J. exp. mar Biol. Ecol. 75: 129-143

Liddle, W. D., Ohlhorst. S. L. (1986). Changes in benthic community composition following mass mortality of Diadema at Jamaica. J. exp. mar Biol. Ecol. 95: 27 $1-278$

Littler, M. M., Littler, D. S. (1984). Relationship between macroalgal functional groups and substrate stability in a subtropical rocky-intertidal system. J. exp. mar. Biol. Ecol. $74 ; 13-34$

Logan, A., Page, F. H., Thomas, M. L. H. (1984). Depth zonation of epibenthos on sublittoral hard substrates off Deer Island, Bay of Fundy, Canada. Estuar. coast. Shelf Sci. 18: 571-592

Lubchenco, J. (1978). Plant species diversity in a marine intertidal community: importance of herbivore food preference and algal competitive abilities. Am. Nat. 112: 23-39

Lubchenco, J. (1980). Algal zonation in the New England rocky intertidal community: an experimental analysis. Ecology 61: 333-344

McGuinness, K. A., Underwood, A. J. (1986) Habitat structure and the nature of communities on intertidal boulders. J. exp. mar. Biol. Ecol. 104: 97-123

Menge, B. A. (1976). Organization of the New England rocky intertidal community: role of predation, competion, and environmental heterogeneity. Ecol. Monogr. 46: 355-393

Menge, B. A. (1979). Coexistence between the seastars Asterias vulgaris and $A$. forbesi in a heterogeneous environment; a non-equilibrium explanation. Oecologia (Berl.) 41: 245-272

Michaud. B. J. (1986). Composition and production of macrobenthic invertebrate communities and food resources of the American lobster Homarus americanus along the
Atlantic coast of Nova Scotia. Ph. D. dissertation, Dalhousie University

Miller, R. J. (1985a). Succession in sea urchin and seaweed abundance in Nova Scotia, Conada. Mar. Biol. 84: 275-286

Miller, R. J. (1985b). Seaweeds, sea urchins, and lobsters: a reappraisal. Can. J. Fish. Aquat. Sci. 42: 2061-2072

Moore, D. S., Yiller, R. J. (1983). Recovery of macroalgae following widespread sea urchin mass mortality with a description of the nearshore hardbottom habitat on the Atlantic coast of Nova Scotia. Can. Tech. Rep. Aquat. Sci. 1230: vii-94

Novaczek, I., McLachlan, J. (1986). Recolonization by algae of the sublittoral habitat of Halifux County, Nova Scotia, following the demise of sea urchins. Botanica mar. 29 $69-73$

Ojeda, F. P., Dearborn, J. H. (1989). Community structure of macroinvertebrates inhabiting the rocky subtidal zone in the Gulf of Maine: seasonal and bathymetric distribution. Mar. Ecol. Prog. Ser. 57:147-161

Olafsson, E. B. (1988). Inhibition of larval settlement to a soft bottom benthic community by drifting algal mats: an experimental test. Mar Biol. 97: 571-574

Osman, R. W. (1977). The establishment and development of a marine epifaunal community. Ecol. Monogr. 47: 37-63

Paine, R. T (1984). Ecological determinism in the competition for space. Ecology 65: 1339-1348

Pearse, J. S., Hines, A. H. (1979). Expansion of a central California kelp forest following the mass mortality of sea urchins. Mar. Biol. 51. 83-91

Raymond, B. G. Scheibling, R. E. (1987). Recruitment and growth of the sea urchin Strongylocentrotus droebachiensis (Muller) following mass mortalities off Nova Scotia, Canada. J. exp. mar. Biol. Ecol. 108: 31-54

Sandnes, O. K., Gulliksen, B. (1980). Monitoring and manipulation of a sublittoral hard bottom biocoenosis in Balsfjord northern Norway. Helgoländer Meeresunters. 33: 467-472

Scheibling, R. E. (1984a). Predation by rock crabs (Cancer irroratus) on diseased sea urchins (Strongylocentrotus droebachiensis) in Nova Scotia. Can. J. Fish. Aquat. Sci. 41: $1847-1851$

Scheibling, R. E. (1984b). Echinoids, epizootics and ecological stability in the rocky subtidal off Nova Scotia, Canada. Helgoländer Meeresunters. 37: 233-242

Scheibling, R. E. (1986). Increased macroalgal abundince following mass mortalities of sea urchins (Strongylocentrotus droebachiensis) along the Atlantic coast of Nova Scotia. Oecologia (Berl.) 68: 186-198

Scheibling, R. E. (1988). Microbial control of sea urchins: Achilles heel or Pandora's box? In: Burke, R. D. Mladenov, P. V., Lambert. P. Parsley, R. L. (eds.) Echinoderm biology, Proc. Sixth Int. Echinoderm Conf., Victona. A. A. Balkema, Rotterdam, p. 745-754

Scheibling, R. E., Stephenson, R. L. (1984). Mass mortality of Strongylocentrotus droebachiensis (Echinodermata: Echinoidea) off Nova Scotia, Canada. Mar. Biol. 78: 153-154

Sousa, W. P. (1979a). Disturbance in marine intertidal boulder fields: the nonequilibrium maintenance of species diversity. Ecology 60: 1225-1239

Sousa, W. P. (1979b). Experimental investigations of disturbance and ecological succession in a rocky intertidal algal community. Ecol. Monogr. 49: 227-254

Steneck, R. S. (1982). A limpet-coralline alga association: adaptations and defenses between a selective herbivore and its prey, Ecology 63: 507-522

Steneck, R. S. (1986). The ecology of coralline algal crusts: convergent patterns and adaptative strategies. Ann. Rev. Ecol. Syst. 17: 273-303 
Thomas, M. L. H., Page, F. H. (1983). Grazing by the gastropod, Lacuna vincta, in the lower intertidal area it Musquash Head, New Brunswick, Canada. J. mar biol. Ass. U. K. $63: 725-736$

Thrush, S. F. (1986). The sublittoral macrobenthic community structure of an Irish sea-lough: effect of decomposing accumulations of seaweed. J. exp. mar. Biol. Ecol. 96: 199-212

Wethey, D. S. (1986). Ranking of settlement cues by barnacle larvae: influence of surface contour Bull. mar Sci. 39 $393-400$

Wharton, W G., Mann, K. H. (1981). Relationship between destructive grazing by the sea urchin Strongylocentrotus

This article was presented by Dr R. J. Conover, Dartmouth, N.S., Canada droebachiensis and the abundance of American lobster Homarus americanus on the Atlintic coast of Nova Scotia. Can. J. Fish. Aquat. Sci. 38: 1339-1349

Witman, J. D. (1985). Refuges, biological disturbance, and rocky subtidal community structure in New England. Ecol. Monogr. 55: 421-445

Witman, J. D. (1987). Subtidal coexistence: storms, grazing mutualism, and the zonation of kelps and mussels. Ecol. Monogr. 57 167-187

Witman, J. D., Suchanek, T H. (1984). Mussels in flow: drag and dislodgement by epizoans. Mar Ecol. Prog. Ser. 16: 259-268

Manuscript first received: September 9, 1989

Revised version accepted: March 14, 1990 